\title{
Thermoregulatory responses of Holstein cows exposed to experimentally induced heat stress
}

\author{
Rodrigo de Andrade Ferrazza ${ }^{a}$, Henry David Mogollón Garcia ${ }^{a}$, \\ Viviana Helena Vallejo Aristizábal ${ }^{\mathrm{a}}$, Camilla de Souza Nogueira ${ }^{\mathrm{b}}$, Cecília José Veríssimo ${ }^{\mathrm{c}}$, \\ José Roberto Sartori ${ }^{\mathrm{b}}$, Roberto Sartori ${ }^{\mathrm{d}}$, João Carlos Pinheiro Ferreira ${ }^{\mathrm{a}, *}$ \\ a Departament of Animal Reproduction and Veterinary Radiology, School of Veterinary Medicine and Animal Science, São Paulo State University. Rua Prof. Dr. Walter \\ Maurício Correa, s/n, 18618-681, Botucatu, SP, Brazil \\ b Departament of Animal Breeding and Nutrition, School of Veterinary Medicine and Animal Science, São Paulo State University. Rua Prof. Dr. Walter Maurício Correa, s/ \\ n, 18618-681, Botucatu, SP, Brazil \\ c Institute of Animal Science, Rua Heitor Penteado, 56, Centro, 13460-000, Nova Odessa, SP, Brazil \\ d Departament of Animal Science, ESALQ, University of São Paulo, Av. Pádua Dias, 11, 13418-900, Piracicaba, SP, Brazil
}

\section{A R T I C L E I N F O}

\section{Keywords:}

Hyperthermia

Thermoregulation

Thermal index

Acclimation

Climate chamber

Bos taurus

\begin{abstract}
A B S T R A C T
Heat stress (HS) adversely influences productivity and welfare of dairy cattle. We hypothesized that the thermoregulatory mechanisms vary depending on the exposure time to HS, with a cumulative effect on the adaptive responses and thermal strain of the cow. To identify the effect of HS on adaptive thermoregulatory mechanisms and predictors of caloric balance, Holstein cows were housed in climate chambers and randomly distributed into thermoneutral (TN; $n=12)$ or HS $(n=12)$ treatments for 16 days. Vaginal temperature (VT), rectal temperature (Tre), respiratory rate (RR), heart rate (HR), and dry matter intake (DMI) were measured. The temperature and humidity under TN were $25.9 \pm 0.2{ }^{\circ} \mathrm{C}$ and $73.0 \pm 0.8 \%$, respectively, and under HS were $36.3 \pm 0.3{ }^{\circ} \mathrm{C}$ and $60.9 \pm 0.9 \%$, respectively. The RR of the HS cows increased immediately after exposure to heat and was higher $(76.02 \pm 1.70 \mathrm{bpm}, \mathrm{p}<0.001)$ than in the TN $(39.70 \pm 0.71 \mathrm{bpm})$. An increase in Tre $\left(39.87 \pm 0.07{ }^{\circ} \mathrm{C}\right.$ in the HS vs. $38.56 \pm 0.03{ }^{\circ} \mathrm{C}$ in the TN, $\left.\mathrm{p}<0.001\right)$ and in VT $\left(39.82 \pm 0.10{ }^{\circ} \mathrm{C}\right.$ in the HS vs. $38.26 \pm 0.03{ }^{\circ} \mathrm{C}$ in the TN, p $\left.<0.001\right)$ followed the increase in RR. A decrease $(\mathrm{p}<0.05)$ in HR occurred in the HS $(62.13 \pm 0.99 \mathrm{bpm})$ compared with the TN $(66.23 \pm 0.79 \mathrm{bpm})$; however, the magnitude of the differences was not the same over time. The DMI was lower in HS cows from the third day (8.27 $\pm 0.33 \mathrm{~kg} \mathrm{~d}^{-1}$ in the HS vs. $14.03 \pm 0.29 \mathrm{~kg} \mathrm{~d}^{-1}$ in the TN, $\left.\mathrm{p}<0.001\right)$, and the reduction of DMI was strongly affected $(\mathrm{r}=-0.65)$ by changes in the temperature humidity index. The effect of environmental variables from the previous day on physiological parameters and DMI was more important than the immediate effect, and ambient temperature represented the most determinant factor for heat exchange. The difference in the responses to acute and chronic exposure to HS suggests an adaptive response. Thus, intense thermal stress strongly influence thermoregulatory mechanisms and the acclimation process depend critically on heat exposure time.
\end{abstract}

\section{Introduction}

Most human and domestic animal populations are located in regions where seasonal stressors negatively influence productivity (Collier et al., 2006), and dairy herds are the most affected by heat stress (HS) among livestock industries in terms of economic losses (St-Pierre et al., 2003). The climate zones differ across the globe and, although some regions, including the Southeastern United States, are hot enough to cause HS during the summer, concerns exist that a potential global warming may worsen the problem (Nardone et al., 2010), decreasing herd productivity (West et al., 2003) and increasing mortality (Vitali et al., 2015).

Heat stress occurs when animals are exposed to temperatures that exceed their thermal comfort zone, and the rate of heat production is higher than the rate of heat dissipation (Aggarwal and Upadhyay, 2013). Several environmental factors, such as, temperature, relative humidity, wind speed, solar radiation, and precipitation may be associate with HS. The temperature humidity index (THI; Thom, 1959) combines the simultaneous effect of temperature and humidity and has been widely used to assess the degree of HS in livestock.

\footnotetext{
* Corresponding author.

E-mail address: jcferreira@fmvz.unesp.br (J.C. Pinheiro Ferreira).
} 
During HS conditions, the efficiency of heat loss is essential for the maintenance of homeothermy (Bligh, 1998). Cattle have evolved a series of physiological mechanisms for dealing with HS, including increase of core body temperature, respiratory and panting rates, sweating, and endocrine system changes (Blackshaw and Blackshaw, 1994; Sanchez et al., 1994; Gaughan et al., 1999). The ability to predict the effects of the climate on the herd is essential to ensure animal welfare and support animal performance and, ultimately, to increase profitability. In addition, evidence exists that the effects of some environmental variables, such as, air temperature, do not have an instantaneous effect; instead, the effect occurs after a delay (West et al., 2003). However, the lag effects of the climate variables on physiological responses have had limited research, particularly in controlled environments.

Although many studies have evaluated the effect of HS on livestock production and unquestionably progress has been achieved in recent years with the improvement of heat mitigation techniques, many efforts still need to be made to elucidate the physiological mechanisms involved in thermoregulation of bovine species. Thus, we postulated that the activation of the thermoregulatory mechanisms vary depending on the duration of heat exposure, with a cumulative effect on the adaptive responses and thermal strain of the cow. Because the dynamic interactions among the components of the animal production system are complex, herein, we tested these hypotheses by isolating the effect of HS, which was experimentally induced in a climate chamber in a continuous and prolonged manner.

Therefore, the objectives of this study were (1) to investigate how the physiological parameters of Holstein cows are affected by HS conditions to understand the activation of adaptive mechanisms for heat dissipation, (2) to determine the best predictors of heat balance, (3) to evaluate the influence of the day shift on physiological parameters, and (4) to determine the effect of duration of heat exposure on the physiological responses.

\section{Materials and methods}

The experiment was conducted at the Lageado Experimental Farm, São Paulo State University, School of Veterinary Medicine and Animal Science (Universidade Estadual Paulista, Faculdade de Medicina Veterinária e Zootecnia - UNESP, FMVZ), Botucatu campus, State of São Paulo, Brazil. The procedures used for animal handling and care were approved by the Animal Research Ethics Committee of the UNESP under protocol No. 86/2013.

\subsection{Cows and adaptation}

Eighteen clinically healthy, nonlactating, pluriparous Holstein cows (Bos taurus) with black and white coats and between 3 and 8 years of age were used. The study was conducted between October and December 2013. Prior to the experiment, the cows were kept in a pasture-based system at the Lageado Experimental Farm. All cows underwent a pretrial period of conditioning to reduce the reactivity and improve the adjustment to the new environment and intensive management. For this purpose, the cows were maintained with halters and were managed and tied with ropes in the pens in increasing periods ranging from $15 \mathrm{~min}$ to $3 \mathrm{~h}$ over 3 weeks in an area close to the climate chambers.

\subsection{Experimental design and facilities}

The experiment was conducted in a completely randomized design with two treatments (TN or HS) and four replicates. Six cows were used in each replicate. Therefore, at the end of the study, each treatment consisted of 12 cows. To avoid a possible carryover effect, cows subjected to HS treatment were not used in the subsequent replicates. The cows were synchronized using Ovsynch protocol (Pursley et al.,
1995) added with an intravaginal progesterone device (Sincrogest, Ourofino, Brazil). Only ovulating cows were selected and housed in the climate chamber.

The climate chamber consisted of a set of two rooms (length of $4.30 \mathrm{~m}$, width of $4.50 \mathrm{~m}$, and height of $2.60 \mathrm{~m}$ ), each with capacity for three cows. The cows were kept in individual pens $(3.00 \times 1.10 \mathrm{~m})$ with a concrete floor covered with rubber mats and had free access to food and water. The temperature control of the climate chamber was automated using a digital temperature controller located outside the chamber and a set of two sensors installed at a height of $1.70 \mathrm{~m}$ inside the chamber. The air was heated by oil and resistance electric heaters. The ambient temperature (Ta) was programmed for the TN and HS groups at $24^{\circ} \mathrm{C}$ and $38^{\circ} \mathrm{C}$, respectively, and maintained during the 16 day experimental period. Two exhaust fans, located on the side walls of each room of the climate chamber, allowed the exchange of air with the outside. Artificial light in the climate chamber was controlled in a 12-h regimen of fluorescent light (7:01 a.m. to 7:00 p.m.) and $12 \mathrm{~h}$ of darkness (7:01 p.m. to 7:00 a.m).

\subsection{Feeding management and diet composition}

All cows were subjected to the same feed management. The cows were fed individually twice a day ( 8 a.m. and 4 p.m.) with a total mixed ration (Table 1), and water ad libitum. The diet was formulated to meet or exceed the nutritional requirements of nonlactating Holstein cows according to the National Research Council recommendations (NRC, 2001). The amount of food offered to each cow was adjusted daily to yield an excess of at least $5 \%$.

Samples of forage and concentrate ingredients were collected weekly and dried at $60{ }^{\circ} \mathrm{C}$ for $72 \mathrm{~h}$ to determine moisture loss. The dried samples were ground in a Wiley mill (Arthur $\mathrm{H}$. Thomas, Philadelphia, PA, USA) in a sieve with a $1 \mathrm{~mm}$ mesh. The variables measured were dry matter content (DM), which was dried in a forced air oven at $105{ }^{\circ} \mathrm{C}$ for $24 \mathrm{~h}$ (AOAC - Association of Official Analytical Chemists, 1990); crude protein (CP), using the Dumas method (Wiles et al., 1998); ether extract (EE; AOAC, 1990); mineral matter (MM; AOAC - Association of Official Analytical Chemists, 1990); neutral detergent fiber (NDF), using sodium sulfite and $\alpha$-amylase (Van Soest et al., 1991); and acid detergent fiber (ADF; Van Soest et al., 1991). Nonfibrous carbohydrates (NFC) were calculated as follows: $100-(C P+N D F+E E+M M)$.

Table 1

Composition of ingredients and nutrients in the diets consumed by cows housed in a climate chamber.

\begin{tabular}{ll}
\hline Ingredients & $\%$ of dry matter \\
\hline Tifton hay & 70.2 \\
Soybean meal & 2.7 \\
Urea & 0.6 \\
Finely ground mature corn & 24.8 \\
Limestone & 0.6 \\
Premix of minerals and vitamins ${ }^{\mathrm{a}}$ & 0.8 \\
Salt & 0.3 \\
Calculated composition & \\
Crude protein (CP) & 13.8 \\
Ether extract (EE) & 3.0 \\
Neutral detergent fiber (NDF) of Tifton & 48.5 \\
Total NDF & 52.2 \\
Total acid detergent fiber (ADF) & 23.1 \\
Mineral matter (MM) & 7.2 \\
Nonfiber carbohydrates (NFC) & 23.8 \\
\hline
\end{tabular}

${ }^{\text {a }}$ Premix of minerals and vitamins: each kilogram contained $52.0 \mathrm{~g}$ of $\mathrm{Zn}, 16.0 \mathrm{~g}$ of Mn, $14.0 \mathrm{~g}$ of $\mathrm{Cu}, 900.0 \mathrm{mg}$ of I, $440.0 \mathrm{mg}$ of Se, $260.0 \mathrm{mg}$ of $\mathrm{Cu}, 34000.0 \mathrm{IU}$ of vitamin E, $5000.0 \mathrm{IU}$ of vitamin A, $1400.0 \mathrm{~g}$ of vitamin D3, and $20.0 \mathrm{~g}$ of monensin.

${ }^{\mathrm{b}}$ Nonfibrous carbohydrates: $100-(\mathrm{CP}+\mathrm{NDF}+$ Ash $+\mathrm{EE})$. 


\subsection{Measurement of physiological variables and dry matter intake}

Vaginal temperature (VT) was recorded every $15 \mathrm{~min}$ by a datarecording device (HOBO $^{\circ}$, Onset Computer Corporation, Bourne, MA, USA) coupled to an intravaginal device without progesterone (Sincrogest ${ }^{\circ}$, Ourofino, Brazil). This experiment was conducted in conjunction with another unrelated experiment in which the removal of the intravaginal thermometer between days 5 and 7 was necessary to allow ovarian follicular aspiration. Respiratory rate (RR), heart rate (HR), and rectal temperature (Tre) were evaluated sequentially twice a day, at 7 a.m. and 3 p.m. Respiratory rate was expressed in breaths per minute (bpm) and was obtained using a timer to count the flank movements of the animal for $30 \mathrm{~s}$, multiplied by 2 to obtain the number of breaths per minute. Heart rate was expressed in beats per minute (bpm) and was obtained using a flexible stethoscope (Standard, Bic Med, SP, Brazil) placed directly into the left thoracic region under one of the auscultation foci for $30 \mathrm{~s}$, multiplied by 2 to obtain the number of beats per minute. Rectal temperature was measured with a large animal clinical thermometer (Model \#5198.6, Incoterm, RS, Brazil) inserted to depth of $3 \mathrm{~cm}$ into the animal's rectum and held to maintain contact with the mucosa for one minute. Body condition score (BCS) was determined at the beginning of the experiment and weekly during the study period. A scale of 1 (thin) to 5 (obese) in increments of 0.25 units was used, as described by Ferguson et al. (1994). A single observer evaluated the BCS throughout the study to minimize variations.

The feed leftovers were weighed once daily before the morning feeding. Dry matter intake (DMI) was determined daily on an individual basis by subtracting the weight of the leftovers from the total amount of feed offered each day. DMI was calculated on the basis of the feed material dried at $105^{\circ} \mathrm{C}$.

\subsection{Collection of environmental data and calculation of the temperature humidity index}

Ambient temperature and relative humidity $(\mathrm{RH})$ were continuously recorded every 30 min using two sensors (HOBO U12 data logger, Onset Computer Co., Bourne, MA, USA) installed at a height of $1.70 \mathrm{~m}$ above the ground in each room of the climate chamber. The THI was calculated from the following mathematical equation proposed by Mader et al. (2006):

$$
\begin{aligned}
T H I & =(0.8 \times D b t)+[(R H / 100) \times(D b t-14.4)]+46.4 \text {,in which Dbt } \\
& =\text { dry bulb temperature, and } \mathrm{RH}=\text { relative humidity } .
\end{aligned}
$$

\subsection{Data processing}

The individual data for $\mathrm{Ta}$ and $\mathrm{RH}$ were obtained using an automatic data-logging system and were used to calculate the THI. The maximum and minimum mean of Ta, RH, and THI were calculated from maximum and minimum daily values, respectively. The mean values of the environmental variables and physiological parameters in the morning (12:00 a.m. to 11:59 a.m.), afternoon (12:00 p.m. to 11:59 p.m.), and daily were calculated to correlate physiological responses and environment variables. To establish HS thresholds, Tre and RR were grouped into three THI intervals using a modified scale initially proposed by Hahn et al. (1999). In addition, to assess the effect of the duration of heat exposure, the first and last four experimental days were established for acute and chronic responses, respectively.

\subsection{Statistical analysis}

The parametric assumptions were tested using Levene's test (homoscedasticity) and the Kolmogorov-Smirnov test (normality). The mean, minimum, and maximum values of the environmental variables were compared between treatments using analysis of variance (ANOVA) followed by Student's $t$-test. Differences were considered significant when $\mathrm{p}<0.05$.

Data with a normal distribution were analyzed using PROC MIXED with repeated measures over time in SAS version 9.4 (SAS Institute Inc., Cary, NC, USA). The effects of treatment, day, and their interaction were included as fixed effects. The Tukey-Kramer test for the comparison of means was used in cases in which a factor or interaction was significant. The statistical model used in the study was expressed by the equation:

$Y_{i j k}=\mu+A_{i}+B(A)_{i j}+C_{k}+A C_{i k}+e_{i j k}$, in which $Y_{i j k}=$ dependent

observation, $\mu=$ overall mean, $A_{i}=$ effect of treatment $\mathrm{i}$,

$B(A)_{i j}=$ effect of cow $j$ under condition $\mathrm{i}, C_{k}=$ effect of day $\mathrm{k}$,

$A C_{i k}=$ effect of the treatment $x$ day interaction, and $e_{i j k}=$ residual.

The model was fitted to the data using the maximum likelihood method. The best matrix was identified using Akaike's information criterion, so the lower the value was, the better the fit of the model in question.

The nonparametric Wilcoxon test was applied to the BCS data, which were non-normally distributed. Significant differences existed when $\mathrm{p}<0.05$, and trends were present when $\mathrm{p}>0.05$ and $\leq 0.1$. All results are expressed as mean and standard error of the mean.

The association between the physiological parameters and the environmental conditions was evaluated using the Pearson correlation test (PROC CORR). The results are presented as correlation coefficients, and significant differences were present when $\mathrm{p}<0.05$. The correlation coefficients were classified as strong $(r>0.6)$, moderate $(0.6 \leq r$ $\geq 0.4$ ), or weak $(r<0.4)$. Regression was performed using the REG procedure of SAS. The models were fitted according to the significance of the regression coefficients $(\mathrm{p}<0.05)$ and according to the coefficients of determination $\left(\mathrm{R}^{2}\right)$ using the following polynomial model:

$$
\begin{aligned}
Y_{i j k}= & \alpha+B x+B x^{2}+B x^{3}+\ldots+B x^{n}, \text { in which } Y_{i j k}=\text { dependent } \\
& \text { observation; } \alpha=\text { constant; and } B x, B x^{2}, B x^{3}, \\
B x^{n}= & \text { estimated regression coefficients. }
\end{aligned}
$$

The effect of environmental factors on the physiological parameters was estimated using multiple regression analysis with PROC REG in SAS. The dependent variables were Tre, VT, RR, HR, and DMI. The independent variables of the initial model included daily mean, minimum, and maximum values for Ta, RH, and THI. The analyses were performed using the forward, backward, and stepwise selection methods. Variables with $\mathrm{p}<0.05$ were retained in the model. The relative contributions of the environmental factors (independent variables) on the dependent variables were determined using partial regression coefficients.

Simple polynomial and linear regressions were constructed using PROC REG in SAS to establish the correlation between the physiological parameters and the THI for acute $0-3$ days) and chronic periods of exposure 13-16 days) to HS.

\section{Results}

\subsection{Environmental conditions}

Ambient temperature, THI, and RH exhibited a treatment effect (p < 0.0001); Ta $\left(36.3 \pm 0.3{ }^{\circ} \mathrm{C}\right.$ vs. $\left.25.9 \pm 0.2{ }^{\circ} \mathrm{C}\right)$ and THI $(88.7 \pm 0.4$ vs. $75.4 \pm 0.3$ ) were higher in the HS group than in the TN group, whereas RH was lower in the HS group $(60.9 \pm 0.9 \%$ vs. $73.0 \pm 0.8 \%)$. A similar result was observed for the mean minimum and maximum values of these variables, except for maximum $\mathrm{RH}$, which was similar ( $p>0.05$ ) between the two treatments (Table 2). The comparison of these variables in the morning and afternoon separately in each experimental environment indicated higher values in the afternoon, except for RH in the TN group, which was higher in the morning 
Table 2

Mean \pm SEM of the environmental conditions in the climate chamber in the thermoneutral (TN) and heat stress (HS) treatments during the experimental period.

\begin{tabular}{lllll}
\hline Variable & Treatment & Minimum & Maximum & Mean \\
\hline Temperature $\left({ }^{\circ} \mathrm{C}\right)$ & TN & $21.77 \pm 0.41^{\mathrm{b}}$ & $30.21 \pm 0.14^{\mathrm{b}}$ & $25.91 \pm 0.22^{\mathrm{b}}$ \\
& HS & $28.19 \pm 0.68^{\mathrm{a}}$ & $43.67 \pm 0.12^{\mathrm{a}}$ & $36.31 \pm 0.34^{\mathrm{a}}$ \\
Humidity (\%) & TN & $54.52 \pm 1.34^{\mathrm{a}}$ & $85.42 \pm 1.12$ & $73.01 \pm 0.79^{\mathrm{a}}$ \\
& HS & $40.59 \pm 1.06^{\mathrm{b}}$ & $84.53 \pm 1.89$ & $60.90 \pm 0.93^{\mathrm{b}}$ \\
$\mathrm{THI}^{1}$ & TN & $69.46 \pm 0.62^{\mathrm{b}}$ & $80.73 \pm 0.31^{\mathrm{b}}$ & $75.42 \pm 0.27^{\mathrm{b}}$ \\
& HS & $77.74 \pm 0.74^{\mathrm{a}}$ & $100.51 \pm 0.53^{\mathrm{a}}$ & $88.66 \pm 0.36^{\mathrm{a}}$
\end{tabular}

${ }^{a-b}$ Different letters in the same column indicate significant differences $(p<0.0001)$ between the treatments.

${ }^{1}$ THI $=$ temperature humidity index.

( $\mathrm{p}<0.01$; Table 3).

\subsection{Physiological variables, BCS, and DMI}

A significant interaction was present between the treatment and day for Tre $(\mathrm{p}<0.0001)$ and VT $(\mathrm{p}<0.01)$ from $12 \mathrm{~h}$ in the climate chamber (afternoon reading), and both variables were higher $(p<0.05)$ for cows under HS treatment. The cows under TN treatment maintained normothermia (Houston and Radostits, 2000) $\left(38.56 \pm 0.03{ }^{\circ} \mathrm{C}\right.$ and $38.26 \pm 0.03{ }^{\circ} \mathrm{C}$ for Tre and VT, respectively), whereas the temperatures of cows under HS were $39.87 \pm 0.07{ }^{\circ} \mathrm{C}$ and $39.82 \pm 0.10{ }^{\circ} \mathrm{C}$ for Tre and VT, respectively (hyperthermia commonly experienced by dairy cows during summer; Fig. 1 and Table 4). Higher means were observed $(\mathrm{p}<0.01)$ in the afternoons than in the mornings, and this effect was always greater for the animals under HS. However, no significant difference in VT ( $p>0.05)$ was observed between the morning and afternoon for cows under HS (Table 3). Thermoneutral treatment caused oscillations of $0.77^{\circ} \mathrm{C}$ in Tre (between the minimum and maximum values), whereas HS caused oscillations of $1.53^{\circ} \mathrm{C}$.

The daily mean RR was $39.70 \pm 0.71$ and $76.02 \pm 1.70 \mathrm{bpm}$ for the TN and HS groups, respectively (Table 4). A significant effect existed from the interaction of the treatment and day; this effect was higher $(\mathrm{p}<0.0001)$ in the HS condition immediately after the cows entered the climate chamber and was high throughout the experimental period
(Fig. 2A). Similar to Tre, the RR was higher ( $p<0.01)$ in the afternoons than in the mornings. The maximum peak of the RR was $130 \mathrm{bpm}$ under HS treatment and $90 \mathrm{bpm}$ under TN treatment (Table 3).

There was interaction between treatment and day $(p<0.03)$ for $\mathrm{HR}$, and this interaction decreased throughout the experimental period for the HS treatment. The mean value observed for HR was $66.23 \pm 0.79 \mathrm{bpm}$ under TN treatment and $62.13 \pm 0.99 \mathrm{bpm}$ under HS treatment. The cows exhibited differences between days, but the magnitude of the differences was not the same over time (Fig. 2B). Heart rate was higher $(\mathrm{p}<0.01)$ in the afternoons in both experimental treatments (Table 3).

The DMI was significantly affected by treatment ( $\mathrm{p}<0.001)$, day $(\mathrm{p}<0.005)$, and treatment $x$ day interaction ( $<<0.005$; Fig. 3). The cows under TN increased their DMI during the experimental period, whereas those under HS decreased their DMI on the third day after entering the climate chamber. Furthermore, the DMI stabilized at approximately $4.04 \mathrm{~kg} \mathrm{~d}^{-1}$ starting on day 15 . The mean daily DMI was higher for the TN treatment $\left(14.03 \pm 0.29 \mathrm{~kg} \mathrm{~d}^{-1}\right)$ than for the HS treatment $\left(8.27 \pm 0.33 \mathrm{~kg} \mathrm{~d}^{-1}\right)$. Despite the difference in DMI, BCS did not change significantly $(\mathrm{p}=0.41)$ between treatments $(3.19 \pm 0.10$ for TN and $3.07 \pm 0.07$ for HS).

\subsection{Correlations and simple regression analysis between physiological responses}

Rectal temperature was positively correlated with VT ( $\mathrm{r}=0.71$; $\mathrm{p}<0.001)$ and $\mathrm{RR}(\mathrm{r}=0.81 ; \mathrm{p}<0.001)$ and negatively correlated with DMI $(\mathrm{r}=-0.62 ; \mathrm{p}<0.001)$. Similarly, RR had a strong positive correlation with VT $(\mathrm{r}=0.67 ; \mathrm{p}<0.001)$ and a negative correlation with the DMI $(r=-0.56 ; \mathrm{p}<0.001)$. No correlation existed between HR and Tre $(r=0.03 ; p=0.45)$ or between HR and RR ( $r=0.002$; $\mathrm{p}=0.95$ ).

The linear regression equations were better fitted and were highly significant $(\mathrm{p}<0.001)$ between Tre and the variables VT, RR, and DMI (Fig. 4). The regression equations indicated a potential increase of $0.8{ }^{\circ} \mathrm{C}$ in VT for each increase of $1{ }^{\circ} \mathrm{C}$ in Tre. Similarly, RR increased an average of $21.6 \mathrm{bpm}$ for each increase of $1{ }^{\circ} \mathrm{C}$ in Tre. Conversely, every increase of $1{ }^{\circ} \mathrm{C}$ in Tre potentially decreased the DMI by $3.8 \mathrm{~kg} \mathrm{~d}^{-1}$.

Table 3

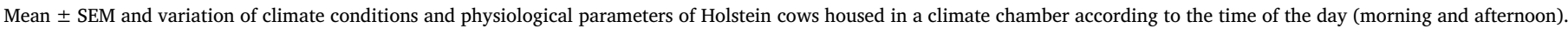

\begin{tabular}{|c|c|c|c|c|}
\hline \multirow[t]{2}{*}{ Variable } & \multicolumn{2}{|l|}{ Thermoneutral } & \multicolumn{2}{|l|}{ Heat stress } \\
\hline & Mean \pm SEM & Variation & Mean \pm SEM & Variation \\
\hline \multicolumn{5}{|c|}{ Air temperature $\left({ }^{\circ} \mathrm{C}\right)$} \\
\hline Morning & $24.49^{b} \pm 0.05$ & $(19.77-29.29)$ & $35.03^{\mathrm{b}} \pm 0.11$ & $(25.23-44.23)$ \\
\hline Afternoon & $26.79^{\mathrm{a}} \pm 0.05$ & $(20.20-31.20)$ & $36.90^{\mathrm{a}} \pm 0.10$ & $(24.03-44.57)$ \\
\hline \multicolumn{5}{|c|}{ Relative humidity (\%) } \\
\hline Morning & $76.07^{\mathrm{a}} \pm 0.15$ & (58.25-97.69) & $61.47^{b} \pm 0.29$ & $(41.00-100.00)$ \\
\hline Afternoon & $71.54^{\mathrm{b}} \pm 0.20$ & $(44.39-91.47)$ & $62.43^{\mathrm{a}} \pm 0.28$ & $(28.51-95.60)$ \\
\hline \multicolumn{5}{|l|}{$\mathrm{THI}^{1}$} \\
\hline Morning & $73.66^{\mathrm{b}} \pm 0.07$ & $(66.35-83.73)$ & $87.01^{b} \pm 0.15$ & $(73.32-101.67)$ \\
\hline Afternoon & $76.59^{\mathrm{a}} \pm 0.06$ & $(67.51-82.50)$ & $89.87^{\mathrm{a}} \pm 0.14$ & $(72.85-04.73)$ \\
\hline \multicolumn{5}{|c|}{ Rectal temperature $\left({ }^{\circ} \mathrm{C}\right)$} \\
\hline Morning & $38.42^{\mathrm{b}} \pm 0.03$ & $(37.60-39.90)$ & $39.42^{\mathrm{b}} \pm 0.06$ & $(37.80-41.60)$ \\
\hline Afternoon & $38.67^{a} \pm 0.03$ & $(37.50-40.00)$ & $40.27^{\mathrm{a}} \pm 0.05$ & $(38.50-41.80)$ \\
\hline \multicolumn{5}{|c|}{ Vaginal temperature $\left({ }^{\circ} \mathrm{C}\right)$} \\
\hline Morning & $38.30^{\mathrm{a}} \pm 0.03$ & $(36.90-39.70)$ & $39.74 \pm 0.10$ & $(37.98-41.24)$ \\
\hline Afternoon & $38.19^{b} \pm 0.02$ & $(37.40-39.50)$ & $39.73 \pm 0.10$ & $(38.20-41.71)$ \\
\hline \multicolumn{5}{|c|}{ Respiratory rate (bpm) } \\
\hline Morning & $36.97^{\mathrm{b}} \pm 0.81$ & $(20.00-66.00)$ & $65.85^{\mathrm{b}} \pm 1.33$ & $(28.00-120.00)$ \\
\hline Afternoon & $42.06^{\mathrm{a}} \pm 1.05$ & $(16.00-90.00)$ & $85.10^{\mathrm{a}} \pm 1.47$ & $(28.00-130.00)$ \\
\hline \multicolumn{5}{|c|}{ Heart rate (bpm) } \\
\hline Morning & $64.62^{\mathrm{b}} \pm 0.79$ & $(36.00-100.00)$ & $59.49^{\mathrm{b}} \pm 0.94$ & $(30.00-120.00)$ \\
\hline Afternoon & $67.62^{\mathrm{a}} \pm 0.79$ & $(42.00-96.00)$ & $63.89^{\mathrm{a}} \pm 0.97$ & $(34.00-126.00)$ \\
\hline
\end{tabular}

${ }^{\mathrm{a}-\mathrm{b}}$ Different letters in the same column indicate significant differences $(\mathrm{p}<0.01)$ between the periods of the day.

${ }^{1} \mathrm{THI}=$ temperature humidity index. 

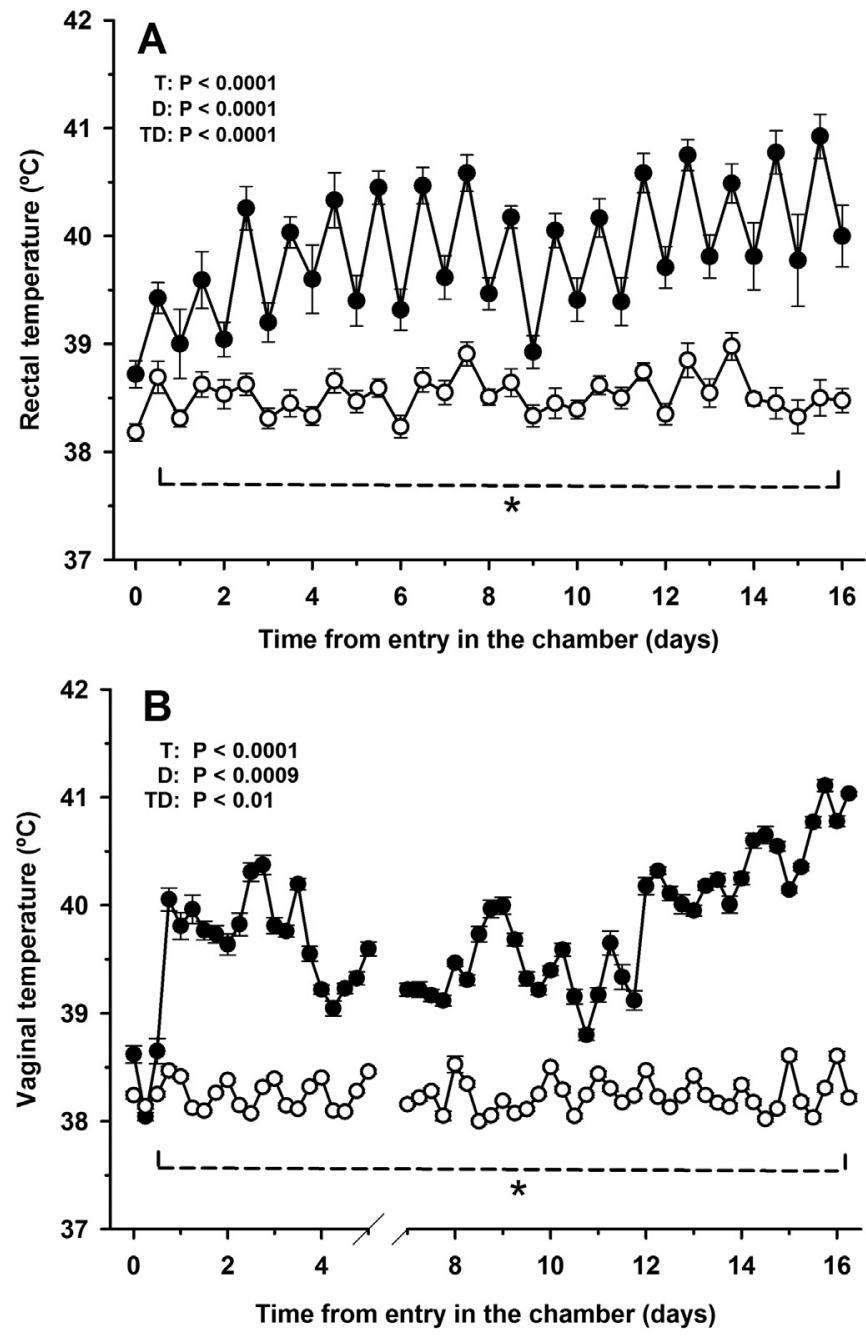

Fig. 1. Mean \pm SEM of rectal temperature (A) and vaginal temperature (B) of cows exposed to thermoneutral $(n=12, O)$ or heat stress $\left(n=12,{ }^{\circ}\right)$ conditions. Probabilities for the main effects ( $\mathrm{T}$, treatment; $\mathrm{D}$, day) and the interaction between treatment and day (TD) are shown. The interval with a significant effect $(\mathrm{p}<0.05)$ of the interaction between treatment and day is indicated by a dotted line with an asterisk $\left(^{*}\right)$. The cut between days 5 and 7 in $\mathrm{B}$ represents the interval when the intravaginal thermometer was removed.

\subsection{Correlations and simple regression analysis between the physiological responses and the environmental variables}

The mean, minimum, and maximum temperatures were positively and strongly correlated with the physiological parameters Tre, VT, and $\mathrm{RR}$ and negatively and strongly correlated with the DMI. A similar correlation was observed between the THI (mean, minimum, and maximum) and the physiological parameters. However, the correlation between RH (mean, minimum, and maximum) and the physiological parameters was weak to moderate. Therefore, the climate variables Ta and THI were more strongly associated with the physiological responses. Moreover, except for maximum $\mathrm{RH}$, all climate variables evaluated (mean, minimum, and maximum Ta; mean and minimum $\mathrm{RH}$; and mean, minimum, and maximum THI) were strongly ( $r>0.60)$ and significantly $(\mathrm{p}<0.001)$ correlated with each other.

The second set of regression equations was generated from the THI model to determine the critical stress threshold of the cows. The THI had a strong positive correlation with Tre $(r=0.81)$, VT $(r=0.77)$ and $\mathrm{RR}(\mathrm{r}=0.81)$ and a negative correlation with DMI $(\mathrm{r}=-0.65)$ and HR $(\mathrm{r}=-0.23)$. The Tre predicted from the THI indicated that the upper critical temperature for adult cattle $\left(39.2^{\circ} \mathrm{C}\right.$; Houston and Radostits,
2000) was reached when the THI was 80 . Similarly, for RR an increase of $20 \mathrm{bpm}$ was observed when the THI increased from 72 to 80 . The decrease in the DMI as a function of the increase in the THI was expressed by $\mathrm{Y}=42.519-0.397 \mathrm{THI}\left(\mathrm{R}^{2}=42.3 \%\right)$ and indicated that, in general, for each unit of increase in THI above 72, the DMI decreased by $0.40 \mathrm{~kg}$ per cow per day.

The effect of the shift of physiological responses and DMI on the mean daily THI during HS was assessed. A slight increase was observed in the regression coefficients of Tre, VT, RR, and DMI when the individual values were shifted forward by one day (Table 5).

\subsection{Multiple regression analyses between environmental variables and physiological responses}

Multiple regression equations were generated to assess the effect and relative importance of the mean, maximum, and minimum environmental variables (independent variables) throughout the experimental period on the physiological responses in the morning and afternoon (dependent variables). The minimum temperature of the previous day $\left(\mathrm{T}_{\text {min-p }}\right)$, the maximum temperature of the previous day $\left(\mathrm{T}_{\text {max-p }}\right)$, the minimum relative humidity of the previous day $\left(\mathrm{RH}_{\min -\mathrm{p}}\right)$, and the minimum THI of the previous day ( $\mathrm{THI}_{\text {min-p }}$ ) affected the morning Tre $\left(\mathrm{Tre}_{1} ; \mathrm{p}<0.0001\right)$ and explained $56.3 \%$ of the variation. The regression coefficients indicated that the most important environmental variables were (in descending order) $\mathrm{T}_{\min -\mathrm{p}}, \mathrm{T}_{\max -\mathrm{p}}, \mathrm{THI}_{\min -\mathrm{p}}$,

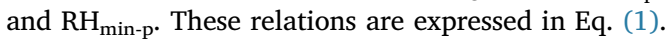

$$
\begin{aligned}
\mathrm{Tre}_{1}= & 38.5+0.214 \mathrm{~T}_{\min -\mathrm{p}}+0.048 \mathrm{~T}_{\max -\mathrm{p}}+0.019 \mathrm{RH}_{\min -\mathrm{p}}-0.107 \\
& \mathrm{THI}_{\min -\mathrm{p}}
\end{aligned}
$$

The afternoon Tre $\left(\mathrm{Tre}_{2}\right)$ was correlated $(\mathrm{p}<0.001)$ with the mean temperature of the previous day $\left(\mathrm{T}_{\text {mean-p }}\right)$, mean relative humidity of the previous day $\left(\mathrm{RH}_{\text {mean-p }}\right)$, and $\mathrm{THI}_{\text {min-p. }}$. The regression coefficients indicated that the environmental variables $\mathrm{T}_{\text {mean-p }}$, $\mathrm{THI}_{\text {min-p }}$, and $\mathrm{RH}_{\text {min- }}$ p were the most important factors (in descending order), explaining $67.2 \%$ of the variation in $\mathrm{Tre}_{2}$ (Eq. (2)):

$\mathrm{Tre}_{2}=38.0+0.297 \mathrm{~T}_{\text {mean }-\mathrm{p}}+0.027 \mathrm{RH}_{\text {mean }-\mathrm{p}}-0.124 \mathrm{THI}_{\text {min }-\mathrm{p}}$

Similar to $\mathrm{Tre}_{1}$, the morning VT $\left(\mathrm{VT}_{1}\right)$ was significantly correlated with the $\mathrm{RH}_{\text {mean-p }}$ but, in contrast to the $\mathrm{Tre}_{1}$, was significantly correlated with the mean THI of the previous day $\left(\mathrm{THI}_{\text {mean-p }}\right)$. These variables explained $64.1 \%$ of the variation in $\mathrm{VT}_{1}$ (Eq. (3)):

$\mathrm{VT}_{1}=32.1-0.022 \mathrm{RH}_{\text {mean }-\mathrm{p}}+0.101 \mathrm{THI}_{\text {mean }-\mathrm{p}}$

The regression coefficients indicated that $\mathrm{THI}_{\text {mean-p }}$ was approximately 4.6 times larger than the $\mathrm{RH}_{\text {mean-p}}$.

Among all the environmental variables studied, only $\mathrm{T}_{\text {mean-p }}$ had no effect $(\mathrm{p}<0.001)$ on the afternoon VT $\left(\mathrm{VT}_{2}\right)$. This relation can be observed in regression Eq. (4), and the $\mathrm{T}_{\text {mean-p }}$ explained $64.4 \%$ of the variation in $\mathrm{VT}_{2}$ :

$\mathrm{VT}_{2}=34.2+0.153 \mathrm{~T}_{\text {mean }-\mathrm{p}}$

The environmental factors that influenced $(\mathrm{p}<0.01)$ the morning $\mathrm{RR}\left(\mathrm{RR}_{1}\right)$ were $\mathrm{T}_{\text {max-p }}, \mathrm{RH}_{\text {min-p }}, \mathrm{RH}_{\text {max }-\mathrm{p}}$, and $\mathrm{RH}_{\text {mean }}$. This relation can be observed in regression Eq. (5) $\left(\mathrm{R}^{2}=61.1 \%\right)$ :

Based on the regression coefficients, the relative importance of the environmental variables was (in descending order) $\mathrm{T}_{\text {max-p }}, \mathrm{RH}_{\text {mean }}$, $\mathrm{RH}_{\text {min-p }}$, and $\mathrm{RH}_{\text {max-p. }}$

$\mathrm{RR}_{1}=-86.6+3.338 \mathrm{~T}_{\max -\mathrm{p}}+0.436 \mathrm{RH}_{\min -\mathrm{p}}-0.406 \mathrm{RH}_{\max -\mathrm{p}}+0.454$

$\mathrm{RH}_{\text {mean }}$

For the afternoon $\mathrm{RR}\left(\mathrm{RR}_{2}\right), \mathrm{THI}_{\max }$ and $\mathrm{RH}_{\text {max-p }}$ were significant sources of variation ( $p<0.01$; Eq. (6)) and explained $69.5 \%$ of the variation in $\mathrm{RR}_{2}$. Based on the regression coefficients, the importance of the environmental variables was (in descending order of importance) $\mathrm{THI}_{\max }$ and $\mathrm{RH}_{\text {max }}$. . 
Table 4

Daily mean, minimum, and maximum values (mean \pm SEM and variation) of climate conditions and physiological parameters of Holstein cows housed in a climate chamber.

\begin{tabular}{|c|c|c|c|c|}
\hline \multirow[t]{2}{*}{ Variable } & \multicolumn{2}{|l|}{ Thermoneutral } & \multicolumn{2}{|l|}{ Heat stress } \\
\hline & Mean \pm SEM & Variation & Mean \pm SEM & Variation \\
\hline \multicolumn{5}{|c|}{ Air temperature $\left({ }^{\circ} \mathrm{C}\right)$} \\
\hline Mean & $25.73^{b} \pm 0.19$ & (21.17-28.10) & $36.04^{\mathrm{a}} \pm 0.41$ & $(30.43-41.85)$ \\
\hline Minimum & $23.11^{\mathrm{b}} \pm 0.19$ & (19.77-25.79) & $31.75^{\mathrm{a}} \pm 0.44$ & $(24.03-38.25)$ \\
\hline Maximum & $28.65^{\mathrm{b}} \pm 0.22$ & $(22.37-31.20)$ & $40.62^{\mathrm{a}} \pm 0.36$ & $(32.07-44.57)$ \\
\hline \multicolumn{5}{|c|}{ Relative humidity (\%) } \\
\hline Mean & $73.62^{\mathrm{a}} \pm 0.70$ & $(60.86-84.97)$ & $61.99^{\mathrm{b}} \pm 0.82$ & $(47.85-76.77)$ \\
\hline Minimum & $63.61^{\mathrm{a}} \pm 1.08$ & (44.39-81.63) & $47.52^{b} \pm 0.78$ & $(28.51-59.27)$ \\
\hline Maximum & $81.00 \pm 0.68$ & (68.93-97.69) & $77.96 \pm 1.06$ & $(56.17-100.00)$ \\
\hline \multicolumn{5}{|l|}{$\mathrm{THI}^{1}$} \\
\hline Mean & $75.24^{b} \pm 0.26$ & $(68.83-78.87)$ & $88.56^{\mathrm{a}} \pm 0.46$ & $(80.38-95.02)$ \\
\hline Minimum & $71.57^{b} \pm 0.31$ & $(66.35-76.67)$ & $81.68^{\mathrm{a}} \pm 0.49$ & $(72.85-88.50)$ \\
\hline Maximum & $79,15^{b} \pm 0.28$ & (70.68-83.73) & $97.53^{\mathrm{a}} \pm 0.43$ & (82.68-104.73) \\
\hline \multicolumn{5}{|c|}{ Rectal temperature $\left({ }^{\circ} \mathrm{C}\right)$} \\
\hline Mean & $38.56^{\mathrm{b}} \pm 0.03$ & $(38.02-39.15)$ & $39.87^{\mathrm{a}} \pm 0.07$ & $(38.33-40.90)$ \\
\hline Minimum & $38.21^{\mathrm{b}} \pm 0.03$ & $(37.50-38.90)$ & $39.08^{\mathrm{a}} \pm 0.09$ & $(37.80-40.70)$ \\
\hline Maximum & $38.98^{\mathrm{b}} \pm 0.05$ & $(38.30-40.00)$ & $40.61^{\mathrm{a}} \pm 0.08$ & $(38.70-41.80)$ \\
\hline \multicolumn{5}{|c|}{ Vaginal temperature $\left({ }^{\circ} \mathrm{C}\right)$} \\
\hline Mean & $38.26^{\mathrm{b}} \pm 0.03$ & $(37.92-38.92)$ & $39.82^{\mathrm{a}} \pm 0.10$ & $(38.32-41.41)$ \\
\hline Minimum & $37.78^{\mathrm{b}} \pm 0.04$ & $(36.90-38.50)$ & $38.80^{\mathrm{a}} \pm 0.13$ & $(37.60-40.90)$ \\
\hline Maximum & $38.79^{b} \pm 0.32$ & $(38.30-39.70)$ & $40.86^{\mathrm{a}} \pm 0.11$ & $(39.00-42.70)$ \\
\hline \multicolumn{5}{|c|}{ Respiratory rate (bpm) } \\
\hline Mean & $39.70^{\mathrm{b}} \pm 0.71$ & $(26.33-60.67)$ & $76.02^{\mathrm{a}} \pm 1.70$ & $(33.33-123.00)$ \\
\hline Minimum & $28.43^{\mathrm{b}} \pm 0.82$ & $(16.00-50.00)$ & $57.12^{\mathrm{a}} \pm 2.12$ & $(28.00-116.00)$ \\
\hline Maximum & $54.55^{\mathrm{b}} \pm 1.60$ & $(32.00-90.00)$ & $95.24^{\mathrm{a}} \pm 2.12$ & $(44.00-130.00)$ \\
\hline \multicolumn{5}{|c|}{ Heart rate (bpm) } \\
\hline Mean & $66.23^{a} \pm 0.79$ & $(52.00-80.00)$ & $62.13^{b} \pm 0.99$ & (49.33-102.50) \\
\hline Minimum & $55.95^{\mathrm{a}} \pm 0.84$ & $(36.00-68.00)$ & $50.79^{\mathrm{b}} \pm 0.97$ & $(30.00-70.00)$ \\
\hline Maximum & $78.31 \pm 1.10$ & $(56.00-100.00)$ & $75.30 \pm 1.57$ & $(54.00-126.00)$ \\
\hline
\end{tabular}

${ }^{\mathrm{a}-\mathrm{b}}$ Different letters in the same row indicate significant differences $(\mathrm{p}<0.001)$ between treatments.

${ }^{1} \mathrm{THI}=$ temperature humidity index.

$\mathrm{RR}_{2}=-124.1+2.264 \mathrm{THI}_{\max }-0.158 \mathrm{RH}_{\max -\mathrm{p}}$

The morning $\mathrm{HR}\left(\mathrm{HR}_{1}\right)$ and afternoon $\mathrm{HR}\left(\mathrm{HR}_{2}\right)$ were affected $(\mathrm{p}<0.001)$ by the environmental variables $\mathrm{T}_{\text {max-p }}, \mathrm{THI}_{\text {max-p }}, \mathrm{THI}_{\text {mean-p}}$, and $\mathrm{RH}_{\text {mean-p. }}$. These factors accounted for $10.8 \%$ and $15.2 \%$ of the variation in $\mathrm{HR}_{1}$ (Eq. (7)) and $\mathrm{HR}_{2}$ (Eq. (8)), respectively:

$$
\begin{aligned}
\mathrm{HR}_{1}= & 136.0+4.706 \mathrm{~T}_{\max -\mathrm{p}}-2.024 \mathrm{THI}_{\max -\mathrm{p}}-1.225 \mathrm{THI}_{\text {mean }-\mathrm{p}}+0.630 \\
& \mathrm{RH}_{\text {mean }-\mathrm{p}} \\
\mathrm{HR}_{2}= & 144.3+5.393 \mathrm{~T}_{\max -\mathrm{p}}-1.524 \mathrm{THI}_{\max -\mathrm{p}}-2.289 \mathrm{THI}_{\text {mean }-\mathrm{p}}+0.843 \\
& \mathrm{RH}_{\text {mean }-\mathrm{p}}
\end{aligned}
$$

The importance of the environmental variables, according to the regression coefficient and in descending order, was Tmax-p, THImax-p, THImean-p, and RHmean-p for HR1 and Tmax-p, THImean-p, THImaxp, and RHmean-p for HR2.

Daily DMI was influenced ( $p<0.001$ ) by the environmental variables $\mathrm{T}_{\text {min-p }}$ and $\mathrm{THI}_{\text {min-p. }}$. The coefficients of the environmental variables $\mathrm{T}_{\text {min-p }}$ and $\mathrm{THI}_{\text {min-p }}$ had, in descending order, a more pronounced effect on the intercept and were the most important factors, explaining $46.2 \%$ of the variation in daily DMI (Eq. (9)):

$\mathrm{DMI}=-2.5-1.510 \mathrm{~T}_{\min -\mathrm{p}}+0.717 \mathrm{THI}_{\min -\mathrm{p}}$

\subsection{Comparison between acute and chronic responses to heat stress}

The acute and chronic thermoregulatory responses to HS (days 0-3 and 13-16, respectively) were compared via regression analysis to assess the short-term acclimation to heat (Fig. 5). The results indicated a difference in the adaptive responses for the variables RR and DMI. For both variables, the slope of the regression equation for the chronic response decreased. The intercept of Tre was larger for the chronic response, and a slight change was observed in the slope between the acute and chronic responses to HS. The acute responses of VT and HR were better represented by linear and quadratic regression models, respectively, but were not significantly correlated $(p>0.05)$ with the chronic response to HS.

\section{Discussion}

Heat stress is responsible for a decrease in productivity and feed efficiency, and its importance in the animal industry has increased, especially in light of the future scenarios on climate change. Therefore, the development of new strategies for heat mitigation that consider the physiological and metabolic adaptations of the animal are needed. This study evaluated the effect of environmental variables and duration of heat exposure on thermoregulatory responses to elucidate the adaptive mechanisms of heat dissipation in cattle under intense thermal stress that was induced experimentally in a continuous and sustained manner.

Methodologically, this study was simulated in a climate chamber to avoid confounding effects and allow the correlation between physiological responses and the intensity and duration of HS. We used nonlactating Holstein cows, which are a more uniform and reliable experimental model for the study objectives because they are not affected by lactation. A constant temperature was used because a single temperature represents a one-dimensional treatment (constant temperature over time). In contrast, a cyclic temperature is a twodimensional treatment (temperature change over time) that can be applied according to a variety of real situations. Much evidence exists to suggest that the severity of HS is largely dependent on the fluctuation of Ta (Maust et al., 1972; Igono et al., 1992; Muller et al., 1994; Silanikove, 2000). Despite Ta changes during the day under natural conditions, consecutive days of heat stress (heat waves) has increased and is predicted to increase further in terms of frequency, intensity, and length in the future (Nidumolu et al., 2014). Thus, in this study, the simplest experimental design assumed a constant temperature to allow 

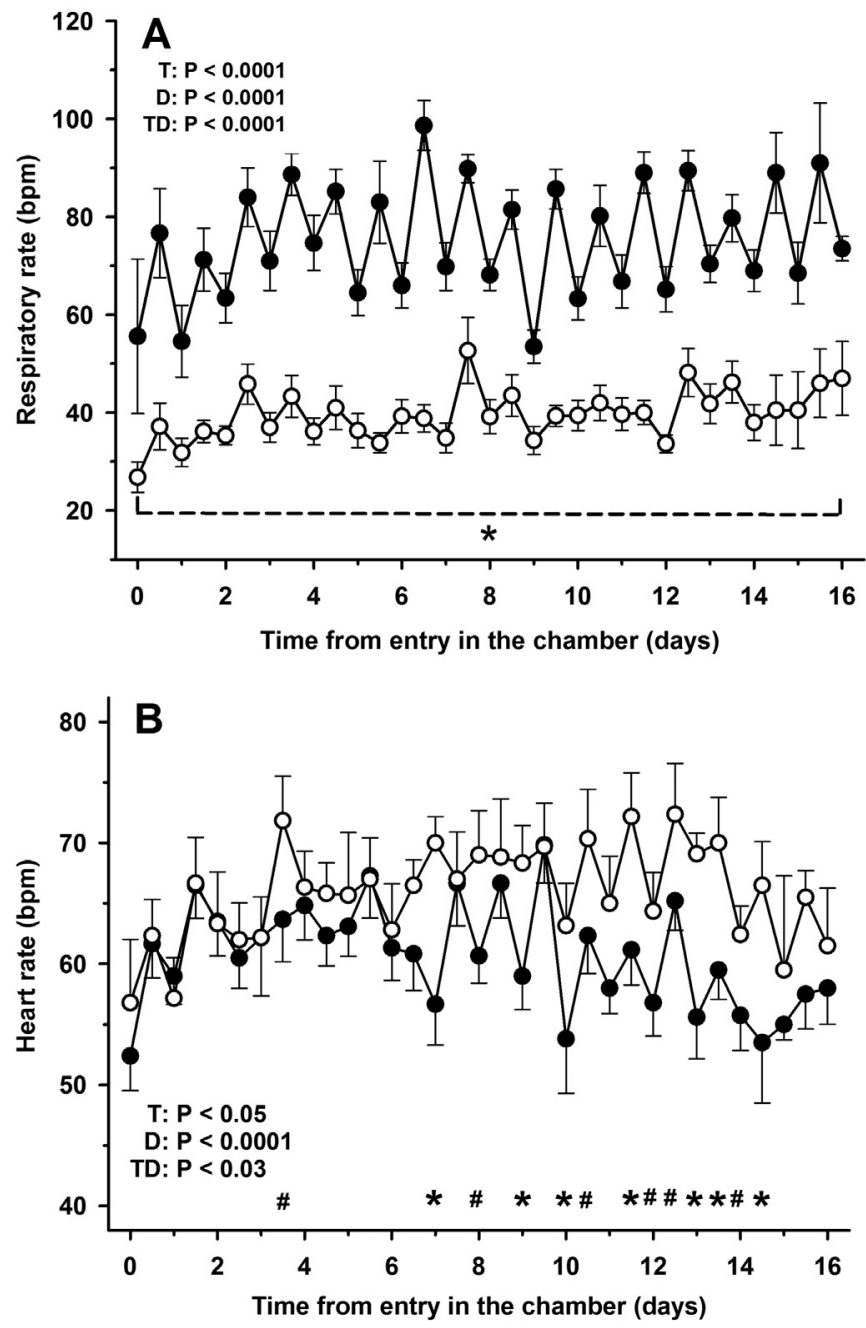

Fig. 2. Mean \pm SEM of respiratory rate (A) and heart rate (B) of cows exposed to thermoneutral $(n=12, O)$ or heat stress $(n=12, \cdot)$ conditions. Probabilities for the main effects (T, treatment; D, day) and the interaction between treatment and day (TD) are shown. The dotted line with an asterisk $\left(^{*}\right)$ indicates the interval with a significant difference $(\mathrm{p}<0.05)$ between treatments. On the day scale, an asterisk $(*)$ indicates the day with a significant difference $(\mathrm{p}<0.05)$ between treatments, and a pound sign $(\#)$ indicates a trend $(\mathrm{p}<0.1)$.

the correlation between the heat status and changes in the physiological parameters over time.

Ambient temperature in the HS treatment was on average $10{ }^{\circ} \mathrm{C}$ higher than the Ta in the TN treatment. The lower humidity in the HS treatment was due to the heating mechanism inherent to the premises of the climate chamber, where higher temperatures coincided with the lowest percentage of humidity. The THI combines the effects of temperature and humidity and has been used to predict HS levels in animals (Mader et al., 2006; Bohmanova et al., 2007). During the experimental period, the mean daily THI in the TN and HS treatments was approximately 75 and 89 , respectively. The maximum mean THI of cows under HS exceeded 100, whereas the minimum mean was approximately 78 (Table 2). Therefore, the cows under HS were subjected to conditions of intense HS for cattle (THI of 90-99; Armstrong, 1994), with higher risk of mortality in dairy cows (Vitali et al., 2015). Although the cows in the TN group were subjected to mild HS conditions (THI of 72-78; Armstrong, 1994), they did not show significant signs of HS, except for a slight increase in their RR. This finding suggests that these THI ranges, although suitable for lactating dairy cows, which are known to be more susceptible to HS (Purwanto et al., 1990), do not seem appropriate for use in evaluating nonlactating dairy taurine cows.

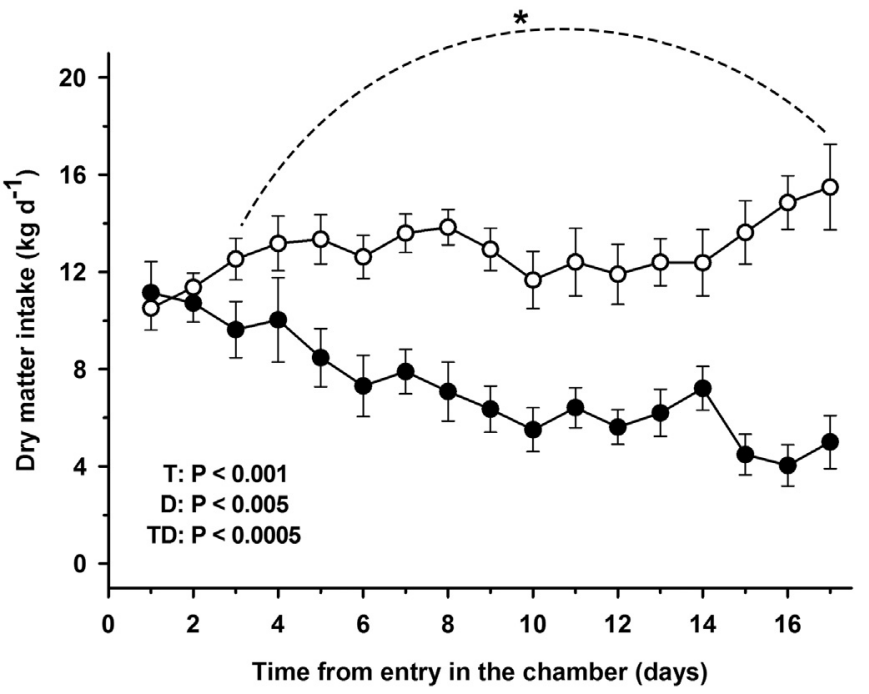

Fig. 3. Mean \pm SEM of dry matter intake of cows exposed to thermoneutral $(n=12,0)$ or heat stress $\left(\mathrm{n}=12,{ }^{\circ}\right)$ conditions. Probabilities for the main effects (T, treatment; $\mathrm{D}$, day) and the interaction between treatment and day (TD) are shown. The dotted line with an asterisk (*) indicates the interval with a significant difference $(\mathrm{p}<0.001)$ between treatments.

The reference values were established at $37.8-39.2{ }^{\circ} \mathrm{C}$ for Tre, 20-30 bpm for RR, and 60-72 bpm for HR (Houston and Radostits, 2000). In the HS treatment, the mean daily Tre was higher than the reference values in $94.1 \%$ and $81.3 \%$ of the morning and afternoon periods, respectively. The RR was higher than the reference values for all day periods. The critical level of $80 \mathrm{bpm}$, limit of thermal strain from which cows can no longer maintain normal body temperature (Smith et al., 2003; Beatty et al., 2006), was reached in $81.3 \%$ of the afternoon periods and was not detected in the mornings. For these reasons, the controlled environmental conditions used herein were assumed effective in causing HS in cows during almost the entire experimental period.

Respiratory rate has been widely used as an indicator of HS in cattle (Gaughan et al., 2000). The increase in RR is an important thermoregulatory mechanism induced to maintain constant body temperature via evaporative cooling. The total heat loss from respiratory tract accounts for approximately $15 \%$ of the total heat dissipation in cattle under heat load (McDowell et al., 1976). However, the pronounced increase and considerable variation in RR observed in this study were not sufficient to prevent hyperthermia in the cows subjected to HS. This result is consistent with other studies in continuous or cycling heat exposure (Pereira et al., 2008; Gaughan et al., 2010; Thompson et al., 2011), which correlated high RR with low thermal tolerance in $B$. taurus.

In the current study, when cows were exposed to HS, the increase in $\mathrm{RR}$ preceded the increase in Tre in $12 \mathrm{~h}$. Likewise, Brown-Brandl et al. (2003) using sensors to record the RR on a continuous basis also detected increase of Tre lagged compared with RR. In adult cows, the maximum mean RR is approximately 70 to $80 \mathrm{bpm}$ (Stevens, 1981). This value is considered an immediate response to heat and is probably associated with a standing position (Berman, 2005). The percentage of cows in a standing position increases linearly with the increase in the THI (Anderson et al., 2013; Allen et al., 2015), which is consistent with the observation that a greater frequency of animals in the standing position is indicative of discomfort (Privolo and Riva, 2009) and laminitis (Sanders et al., 2009). Therefore, if we consider that the change in RR precedes the change in Tre, RR could be used as a predictor of the heat status. With this assumption, visual inspection of the respiratory response allows the alleviation of HS before a significant increase occurs in body temperature, interfering in normal body functions. 

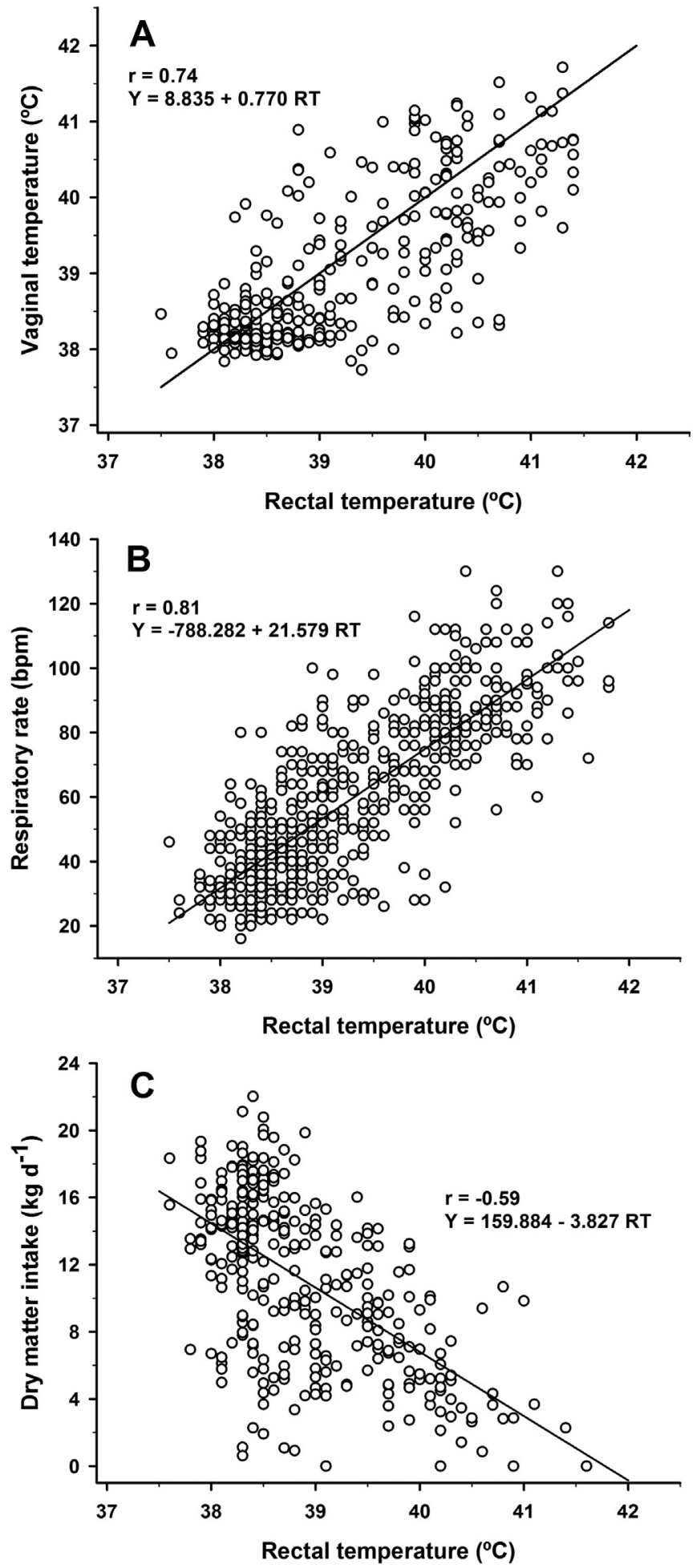

Fig. 4. Linear models showing the correlation between rectal temperature and vaginal temperature (A), respiratory rate (B) and dry matter intake (C). The points represent individual observations, and the line represents the regression equation. The information on the chart refers to the linear regression at the points indicated.

In this study, exposure to a heat load much higher than the thermal comfort zone in cattle $\left(25-26^{\circ} \mathrm{C}\right.$; Berman et al., 1985) resulted in a marked increase in all the body temperature variables measured. The use of technologies that allow the frequent and automated recording of body temperature (such as an intravaginal thermometer) provide the additional advantage of capturing diurnal changes (Vickers et al., 2010; Burdick et al., 2012). Rectal temperature and VT were strongly
Table 5

Effect of shift forward or backward in the dependent variables (rectal temperature, vaginal temperature, respiratory rate, heart rate, and dry matter intake) in relation to temperature humidity index on the coefficient of determination $\left(\mathrm{R}^{2}\right)$ of the regressions.

\begin{tabular}{llllll}
\hline Dependent variable & Slope & SEM $_{\text {slope }}$ & $\mathrm{t}$ & $\mathrm{p}$ value & $\mathrm{R}^{2}(\%)$ \\
\hline Rectal temperature $\left({ }^{\circ} \mathrm{C}\right)$ & & & & & \\
$\quad$ Previous day & 32.084 & 0.315 & 101.83 & $<0.0001$ & 59.53 \\
$\quad$ Current day & 31.609 & 0.285 & 110.83 & $<0.0001$ & 65.97 \\
$\quad$ Following day & 31.504 & 0.288 & 109.52 & $<0.0001$ & 67.81 \\
Vaginal temperature $\left({ }^{\circ} \mathrm{C}\right)$ & & & & & \\
$\quad$ Previous day & 30.295 & 0.570 & 53.17 & $<0.0001$ & 58.37 \\
$\quad$ Current day & 30.042 & 0.584 & 51.47 & $<0.0001$ & 59.50 \\
$\quad$ Following day & 29.655 & 0.587 & 50.51 & $<0.0001$ & 61.83 \\
Respiratory rate $(\mathrm{bpm})$ & & & & & \\
$\quad$ Previous day & -144.413 & 8.388 & -17.22 & $<0.0001$ & 62.70 \\
$\quad$ Current day & -150.276 & 7.897 & -19.03 & $<0.0001$ & 65.53 \\
$\quad$ Following day & -143.976 & 7.584 & -18.99 & $<0.0001$ & 67.48 \\
Heart rate (bpm) & & & & & \\
$\quad$ Previous day & $\mathrm{NS}$ & $\mathrm{NS}$ & $\mathrm{NS}$ & $\mathrm{NS}$ & $\mathrm{NS}$ \\
$\quad$ Current day & 88.807 & 5.528 & 16.06 & $<0.0001$ & 5.32 \\
$\quad$ Following day & $\mathrm{NS}$ & $\mathrm{NS}$ & $\mathrm{NS}$ & $\mathrm{NS}$ & $\mathrm{NS}$ \\
$\quad$ Dry matter intake $\left(\mathrm{kg} \mathrm{d}{ }^{-1}\right)$ & & & & & \\
$\quad$ Previous day & 41.854 & 2.167 & 19.32 & $<0.0001$ & 39.66 \\
$\quad$ Current day & 42.519 & 2.095 & 20.30 & $<0.0001$ & 42.29 \\
$\quad$ Following day & 44.068 & 2.139 & 20.60 & $<0.0001$ & 44.33 \\
\hline
\end{tabular}

correlated with each other $(\mathrm{r}=0.71)$, and a diurnal pattern was observed. The means were higher in the afternoons than in the mornings, and this effect was greater in animals under HS. Effective environmental temperatures that were higher in the afternoon (particularly in the HS treatment) and associated with an elevated body temperature generated by the circadian rhythm (Shehab-El-Deen et al., 2010) were the factors responsible for these effects. The range of Tre (daily maximum mean Tre - daily minimum mean Tre) of the cows under TN and HS conditions was approximately $0.8^{\circ} \mathrm{C}$ and $1.5^{\circ} \mathrm{C}$, respectively. These values were similar to those obtained in the winter $\left(0.4{ }^{\circ} \mathrm{C}\right)$ and summer $\left(1.2{ }^{\circ} \mathrm{C}\right)$ for dairy cows under field conditions (Berman and Morag, 1971).

Our results indicated that HR was not influenced at the same magnitude as RR, Tre or VT. In the present study, we observed a gradual decrease in HR in the cows under HS compared with cows under TN. Conflicting results on HR have been reported in continuous heat exposure studies (Richards, 1985; Beatty et al., 2006). The decrease in HR associated with HS can be attributed to heat exchange with the environment, so the duration of exposure to high temperatures appears to be essential for adaptation in cows. In a trial of continuous exposure to HS during seven days, Cowley et al. (2015) also observed a decrease in HR both in heat stressed lactating cows as well as in thermoneutral pair-fed lactating cows. This finding is a possible explanation for our results. So it is likely that the decrease in HR is a side effect associated with DMI due to the slower metabolism, decreased visceral blood flow, and decreased peripheral vasodilatation.

Dry matter intake was strongly influenced by the experimental conditions. A linear decrease in voluntary DMI with increasing Tre was detected for cow in this study, which was proven by the moderate correlation $(r=-0.59)$. These results are consistent with those of Bernabucci et al. (1999), in a continuous exposure of dairy heifers to HS, and Brown-Brandl et al. (2003), in a cycling exposure of beef cattle to HS. The decrease in DMI is followed by the decrease in the metabolic rate and a decrease in heat production, which contributes to the maintenance of heat balance (Turner and Taylor, 1983). The lower DMI in HS cows is associated with high-fiber diets with low degradability (Beede and Collier, 1986; Forbes, 1993). The selectivity of the diet is increased, whereas the forage intake in relation to the concentrate is decreased in an attempt to reduce body heat derived from fermentation, digestion, and other metabolic processes (Beede and Collier, 1986). Additionally, food intake was not affected at temperatures between $15{ }^{\circ} \mathrm{C}$ and $25^{\circ} \mathrm{C}$, but the increase in Ta to values higher 

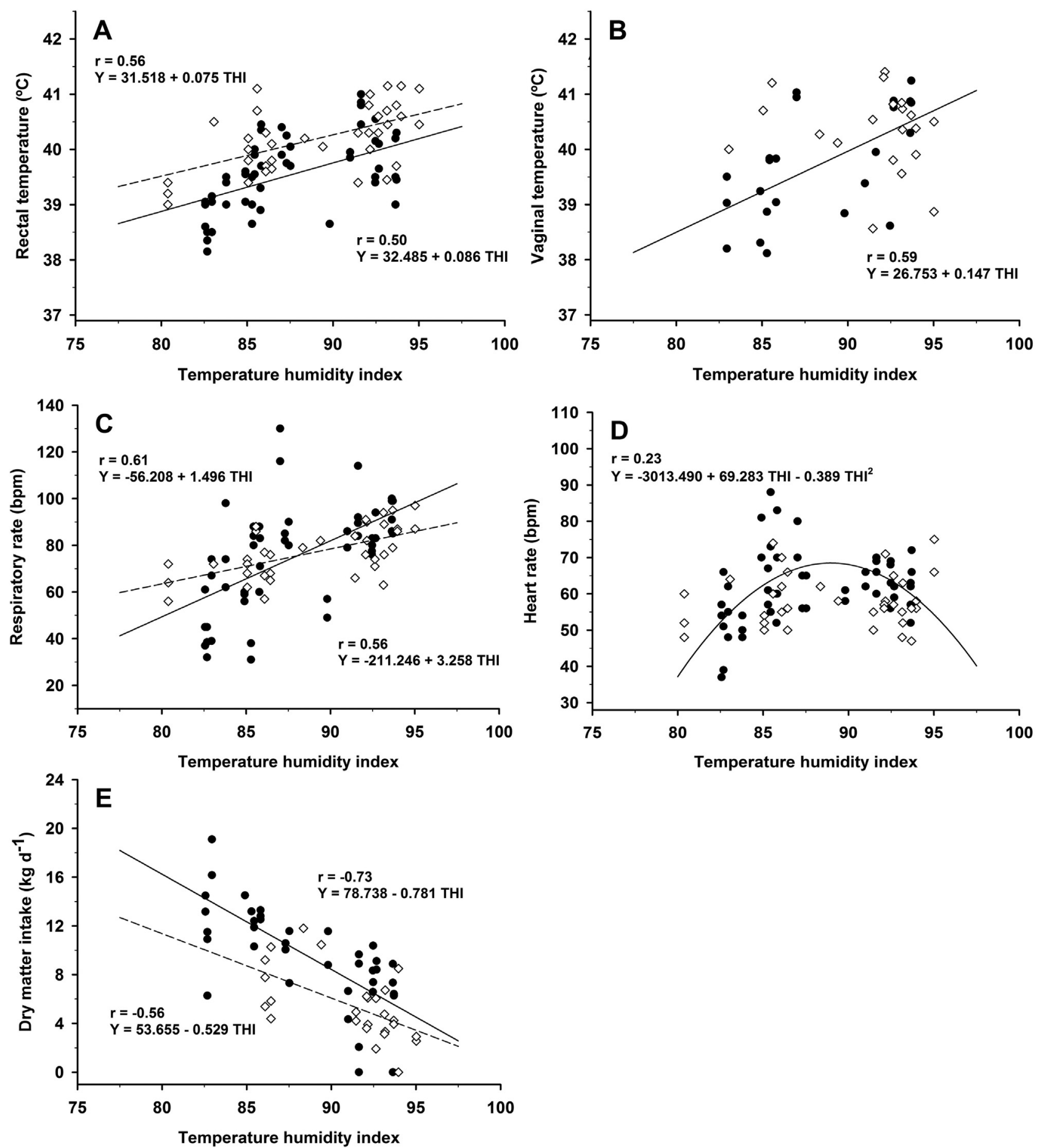

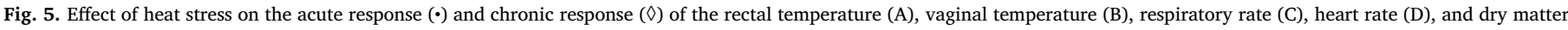

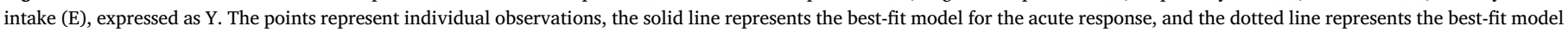
for the chronic response to heat stress. No correlation ( $p>0.05$ ) was observed between vaginal temperature and heart rate for the sustained response to heat stress.

than $35^{\circ} \mathrm{C}$ decreased food intake by $10-35 \%$ (Conrad, 1985). In the present study, the marked reduction in DMI under HS conditions was greater than $30 \%$ compared with cows under TN conditions. The constant temperature used in this study may have exceeded the expected response to HS. Lower cyclical temperatures at night would have allowed greater food intake because the cows would be able to dissipate the heat accumulated during the day (Maust et al., 1972), allowing changes in some of the observed responses.

A considerable energetic cost is known to be necessary to dissipate stored heat, with a consequent increase in maintenance requirements
(Beede and Collier, 1986; NRC, 2001). During acute HS, the cows may be in negative energy balance (Shwartz et al., 2009), compatible with high plasma concentrations of $\beta$-hydroxybutyric acid (Soriani et al., 2013), so the nutrient intake cannot supply the energy requirements. Later, leveled off or compensatory food consumption occurs (BrownBrandl et al., 2003), which was observed in our study only after day 15. Moreover, a redistribution of blood flow from the digestive system (Hales et al., 1984) to peripheral tissues occurs in animals chronically exposed to heat. This hypothesis is supported by the cardiovascular adjustments discussed previously. 
In addition to the changes observed in physiological parameters and DMI, clinical signs of HS, including open-mouth panting, drooling, reluctance or inability to rise, increased coat licking, and dullness, and neurological signs, such as fixed gaze and glazed eyes, were also observed in the present study, as previously reported by Beatty et al. (2006).

The correlation coefficients between Tre, VT, RR, DMI, and THI from the previous day were higher than the current or following day, indicating a period of delay before the response to climate variation develops fully. In fact, the delayed effect of the environmental factors on DMI seems logical because of the time necessary for cows to consume, digest, and metabolize nutrients. The development of HS prediction models that reflect individual variations in physiological parameters on the basis of experimental evidence can be useful to estimate the heat status of cattle in a wide variety of environmental conditions and can allow prediction of the onset of HS. This would make it possible to explore, for example, food supplementation strategies or environmental changes. Therefore, these data have important implications for the prediction models that typically depend on weather data measured on the same day to predict performance responses (West et al., 2003).

Measurements of HS can help farmers keep cows at an ideal temperature and prevent adverse effects caused by heat. Rectal temperature is an important indicator of thermal balance. An increase in Tre indicates failure or exhaustion of the thermoregulatory mechanisms. A negative correlation between Tre and DMI was detected ( $\mathrm{r}$ $=-0.59$ ) and was the best single predictor of HS compared with other physiological parameters, in agreement with previous data on lactating cows (Spiers et al., 2004). Moreover, in this study, the correlation analysis demonstrated that DMI was strongly affected by environmental variables $(r=-0.65)$. The combination of high Ta and high $\mathrm{RH}$ increases the level of stress. Therefore, the estimated weather variables, including the THI, can describe precisely the effect of environmental conditions on the magnitude of the hyperthermia experienced by cows under HS. These results motivate the use of the THI as an adequate variable to predict the severity of HS, with the advantage that the measurement of the THI is straightforward and indirect.

Heat stress during the dry period may influence negatively the calf birth weight and subsequent lactation (Amaral et al., 2009; Tao et al., 2011), resulting in large economic losses (Ferreira et al., 2016). The definition of stress thresholds can provide useful information for decision-making in the management of cows, particularly with regard to thermal comfort (Mader et al., 2010). In the present study, although the upper individual critical Tre established for cattle $\left(39.2^{\circ} \mathrm{C}\right.$; Houston and Radostits, 2000) was reached with a THI of 80 , the grouping of THI at intervals of severity of HS (Fig. 6) indicated that the adoption of a

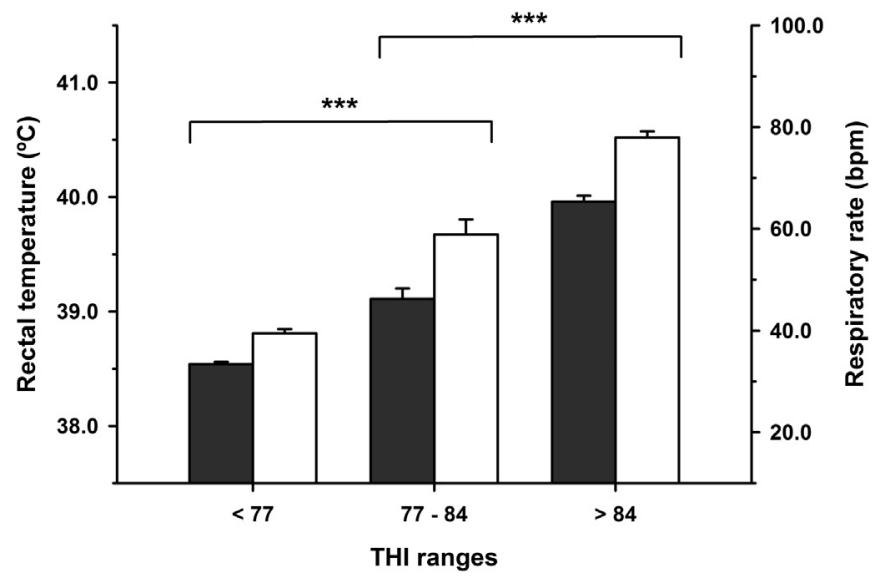

Fig. 6. Mean \pm SEM of rectal temperature (black bars) and respiratory rate (white bars) grouped into three intervals of daily temperature humidity index (THI). Asterisks indicate significant differences $(p<0.001)$ between the intervals for both variables.
THI below 77 as a critical threshold for dry cows included all animals. Despite the differences in the HS threshold values in the different regions, animal categories, and methodologies for the calculation, a THI value of 72 has been continuously used as a reference (Bohmanova et al., 2007; Aguilar et al., 2010). Other studies have found a limit of 74 for the THI in the semi-arid regions of the United States (Bohmanova et al., 2007), 69 under the climate conditions of Tunisia (Bouraoui et al., 2002), and 60 for protein yield in German Holstein cows (Brügemann et al., 2011). The difference between the studies provides insights into the increased production of the metabolic heat generated by dairy cows, as demonstrated by Purwanto et al. (1990), wherein lowyielding dairy cows $(18.5 \mathrm{~kg} /$ day) and high-yielding dairy cows (31.6 kg/day) were compared to nonlactating cows and found to generate $27 \%$ and $48 \%$ more heat, respectively. Therefore, the current values may be overestimated for the category of cows that are not lactating and suggests caution in the use of general indicators that do not include a consideration of the level of animal production.

Multiple regression analysis showed that Ta represented the most determinant factor for heat exchange, although the THI affected VT primarily in the morning and RR primarily in the afternoon. Ambient temperature and THI are closely related and the effects are difficult to separate. In other hand, the RH seemed to have a limited impact on physiological parameters and was an additional stress factor, as reported previously by Maust et al. (1972), with an increasing effect on RR, which is consistent with the fact that heat is removed from the lungs in the form of moisture (Gebremedhin et al., 2008). In addition, $\mathrm{RR}$ is a thermoregulatory mechanism, whereas Tre is the result of thermal balance (Berbigier, 1988). Therefore, the influence of thermal variables on RR may be mediated via different intermediate Tre mechanisms (Kabuga, 1992). In agreement with these findings, Ta had a stronger effect on physiological parameters (Legates et al., 1991; Kabuga, 1992) and milk temperature (West et al., 2003) in field conditions, although humidity seems to be a limiting factor in humid climates (Bohmanova et al., 2007).

The $\mathrm{R}^{2}$ value for the environmental variables that influenced HR was relatively low and explained $15 \%$ or less of the total variation. This result demonstrated that, the environmental conditions had a relatively small effect on HR and suggested that other sources of variation are more important than the weather, such as food intake. In the study by Kabuga (1992), climatic variables had the greatest influence on HR and explained $25.4 \%$ and $22.1 \%$ of the variation in the morning and afternoon, respectively. However, $\mathrm{R}^{2}$ values obtained for Tre, RR, and DMI in this study were higher compared with other field studies (Maust et al., 1972; Kabuga, 1992; West et al., 2003). These differences might be explained by the lower variation of experimental conditions in laboratory and the difference in the production level and dietary composition among the studies.

The minimum Ta and minimum THI from the previous day were more important to explain the variation in DMI than the immediate effect. The environmental factors from the current day were largely ignored. This delayed effect in the DMI and physiological responses has previously been reported in a field experiment using lactating dairy cows by West et al. (2003) and Kabuga (1992), but differs from the results of Maust et al. (1972), wherein the correlations between Tre and DMI and climate conditions were higher in the same day. Moreover, the relative importance of minimum values may be partially explained by the continuous exposure to heat, so the opportunity to dissipate heat is reduced, leading to greater DMI when Ta and THI values are lower.

The acute and chronic effects of HS were explained by the different regression lines. The RR and DMI results indicated differences between the acute and chronic responses to exposure to heat stress, providing evidence of an adaptive physiological adjustment to heat over time. However, no decrease in Tre was observed in the cows. These findings were similar to those obtained with dairy cows (Kibler et al., 1965) but differed from those obtained with heifers, in which prolonged exposure to heat caused a gradual decrease in Tre (Bernabucci et al., 1999). The 
difference between the results may be due to the duration of treatments, and a longer time may be necessary for the animals to balance Tre and acclimatize effectively. The decrease in RR observed in the chronic response was consistent with the results of another study under conditions of continuous and prolonged HS (Beatty et al., 2006) but different from the study conducted under controlled conditions using cyclic temperatures (Scharf et al., 2010). The fluctuation in Ta in the latter study provided an opportunity for the animals to dissipate heat and maintain homeothermy (Igono et al., 1992; Muller et al., 1994) and may explain the discrepancy between the results obtained. Moreover, there may be an upper limit for RR (Spiers et al., 2004). Therefore, the decrease in RR is not always an indication that the animal is coping with the heat and may be due to changes in the respiratory dynamics associated with moving from a state of rapid open-mouth breathing to deeper slower-paced open mouth breathing (Gaughan et al., 2000). Dry matter intake sharply decreased after exposure to HS (acute phase). The difference between the DMI regression coefficients of the acute and chronic responses may indicate an adaptation to thermally stressful conditions and partial acclimatization after decrease in DMI over the first several days (Fig. 3). The food intake in B. taurus heifers (Beatty et al., 2006) and in cross-bred steers (Brown-Brandl et al., 2003) significantly decreased and had a slight recovery three and seven days after continuous heat exposure, respectively. Lactating cows continuously exposed to a constant temperature of $29^{\circ} \mathrm{C}$ had stabilization of DMI four to five weeks after exposure (Kibler et al., 1965). Therefore, following the sharp decrease in DMI during the acute phase, adjustments in the nutrient requirements via reduction of the weight of visceral organs (Koong et al., 1985; Ferrell et al., 1986), changes in the expression of pre-existing characteristics coordinated by the endocrine system (Bernabucci et al., 2010), and subsequent stabilization of DMI over time seem to occur. In this study, the cows were not completely acclimatized, perhaps because of the intense HS conditions used and the need for exposure for a longer period. Thus, further studies are necessary to elucidate the period and dynamics of chronic responses to HS.

\section{Conclusion}

In summary, continuous exposure to intense HS influences thermoregulatory mechanisms, leading to a marked increase in RR, followed by an increase in Tre. Other responses include a decrease in DMI in an attempt to minimize total heat load and suggest the induction of metabolic shifts, redistribution of blood flow, and decrease in HR as part of the physiological adaptations. The influence of environmental variables from the previous day on physiological parameters and DMI is more important than the immediate effect and Ta represents the most determinant factor for heat exchange. Although prolonged exposures to HS indicate an adaptive adjustment, in this study the acclimation process was only partial.

\section{Acknowledgements}

The authors are grateful to Dr. José Carlos F. Pantoja from FMVZ UNESP (Botucatu, São Paulo, Brazil) for assistance with the statistical analyses and to American Journal Experts for assistance with language editing. This research was supported by FAPESP [Grant\#2012/182977, Grant\#2013/20083-8 (doctoral fellowship to the first author)].

\section{References}

Aggarwal, A., Upadhyay, R., 2013. Heat Stress and Animal Productivity. Springer, India. Aguilar, I., Misztal, I., Tsuruta, S., 2010. Short communication: genetic trends of milk yield under heat stress for US Holsteins. J. Dairy Sci. 93, 1754-1758.

AOAC - Association of Official Analytical Chemists, 1990. Official Methods of Analysis, 15th ed. AOAC, Washington, D.C., pp. 1298.

Allen, J.D., Hall, L.W., Collier, R.J., Smith, J.F., 2015. Effect of core body temperature, time of day, and climate conditions on behavioral patterns of lactating dairy cows experiencing mild to moderate heat stress. J. Dairy Sci. 98, 118-127.

Amaral, B.C., Tao, S., Hayen, J., Connor, E.E., Bubolz, J., Dahl, G.E., 2009. Heat stress abatement during the dry period: does cooling improve transition into lactation? J. Dairy Sci. 92, 5988-5999.

Anderson, S.D., Bradford, B.J., Harner, J.P., Tucker, C.B., Choi, C.Y., Allen, J.D., Hall, L.W., Rungruang, S., Collier, R.J., Smith, J.F., 2013. Effects of adjustable and stationary fans with misters on core body temperature and lying behavior of lactating dairy cows in a semiarid climate. J. Dairy Sci. 96, 4738-4750.

Armstrong, D.V., 1994. Heat stress interaction with shade and cooling. J. Dairy Sci. 77, 2044-2050.

Beatty, D.T., Barnes, A., Taylor, E., Pethick, D., McCarthy, M., Maloney, S.K., 2006. Physiological responses of Bos taurus and Bos indicus cattle to prolonged, continuous heat and humidity. J. Anim. Sci. 84, 972-985.

Beede, D.K., Collier, R.J., 1986. Potential nutritional strategies for intensively managed cattle during thermal stress. J. Anim. Sci. 62, 543-554.

Berbigier, P., 1988. Bioclimatologie des Ruminants Domestiques en Zone Tropicale, 1st ed. INRA, Paris.

Berman, A., Folman, Y., Kaim, M., Mamen, M., Herz, Z., Wolfenson, D., Arieli, A., Graber, Y., 1985. Upper critical temperatures and forced ventilation effects for high-yielding dairy cows in a subtropical climate. J. Dairy Sci. 68, 1488-1495.

Berman, A., 2005. Estimates of heat stress relief needs for Holstein dairy cows. J. Anim. Sci. $83,1377-1384$.

Berman, A., Morag, M., 1971. Nychthemeral patterns of thermo-regulation in highyielding dairy cows in a hot dry near-naturalclimate. Aust. J. Agric. Res. 22, 671-680.

Bernabucci, U., Lacetera, N., Baumgard, L.H., Rhoads, R.P., Ronchi, B., Nardone, A., 2010. Metabolic and hormonal acclimation to heat stress in domesticated ruminants. Animal 4, 1167-1183.

Bernabucci, U., Bani, P., Ronchi, B., Lacetera, N., Nardone, A., 1999. Influence of shortand long-term exposure to a hot environment on rumen passage rate and diet Digestibility by Friesian Heifers. J. Dairy Sci. 82, 967-973.

Blackshaw, J.K., Blackshaw, A.W., 1994. Heat stress in cattle and the effect of shade on production and behaviour: a review. Aust. J. Exp. Agric. 34, 285-295.

Bligh, J., 1998. Mammalian homeothermy: an integrative thesis. J. Therm. Biol. 23, $143-258$.

Bohmanova, J., Misztal, I., Cole, J.B., 2007. Temperature-humidity indices as indicators of milk production losses due to heat stress. J. Dairy Sci. 90 (4), 1947-1956.

Bouraoui, R., Lahmar, M., Majdoub, A., Djemali, M., Belyea, R., 2002. The relationship of temperature-humidity index with milk production of dairy cows in a Mediterranean climate. Anim. Res. 51, 479-491.

Brown-Brandl, T.M., Nienaber, J.A., Eigenberg, R.A., Hahn, G.L., Freetly, H., 2003. Thermoregulatory responses of feeder cattle. J. Therm. Biol. 28, 149-157.

Brügemann, K., Gernand, E., Von Borstel, U.U., König, S., 2011. Genetic analyses of protein yield in dairy cows applying random regression models with time-dependent and temperature x humidity-dependent covariates. J. Dairy Sci. 94, 4129-4139.

Burdick, N.C., Carroll, J.A., Dailey, J.W., Randel, R.D., Falkenberg, S.M., Schmidt, T.B., 2012. Development of a self-contained, indwelling vaginal temperature probe for use in cattle research. J. Therm. Biol. 37, 339-343.

Collier, R.J., Dahl, G.E., VanBaale, M.J., 2006. Major advances associated with environmental effects on dairy cattle. J. Dairy Sci. 89, 1244-1253.

Conrad, J.H., 1985. Feeding of farm animals in hot and cold environments. In: Yousef, M.K. (Ed.), Stress Physiology in Livestock 1. CRC Press, Boca Raton, FL, pp. 205-226.

Cowley, F.C., Barber, D.G., Houlihan, A.V., Poppi, D.P., 2015. Immediate and residual effects of heat stress and restricted intake on milk protein and casein composition and energy metabolism. J. Dairy Sci. 98, 2356-2368.

Ferguson, J.D., Galligan, D.T., Thomsen, N., 1994. Principal descriptors of body condition score in Holstein cows. J. Dairy Sci. 77, 2695-2703.

Ferreira, F.C., Gennari, R.S., Dahl, G.E., De Vries, A., 2016. Economic feasibility of cooling dry cows across the United States. J. Dairy Sci. 99, 1-11.

Ferrell, C.L., Koong, L.J., Nienaber, J.A., 1986. Effect of previous nutrition on body composition and maintenance energy costs of growing lambs. Br. J. Nutr. 56, 595-605.

Forbes, J.M., 1993. Voluntary feed intake. In: Forbes, J.M., France, J. (Eds.), Quantitative Aspects of Ruminant Digestion and Metabolism. CAB International, Devon, pp. 479-494.

Gaughan, J.B., Mader, T.L., Holt, S.M., Sullivan, M.L., Hahn, G.L., 2010. Assessing the heat tolerance of 17 beef cattle genotypes. Int. J. Biometeorol. 54, 617-627.

Gaughan, J.B., Mader, T.L., Holt, S.M., Josey, M.J., Rowan, K.J., 1999. Heat tolerance of Boran and Tuli crossbred steers. J. Anim. Sci. 77, 2398-2405.

Gaughan, J.B., Holt, S.M., Hahn, G.L., Mader, T.L., Eigenberg, R., 2000. Respiration rate: is it a good measure of heat stress in cattle? Asian Aust. J. Anim. 13, 329-332.

Gebremedhin, K.G., Hillman, P.E., Lee, C.N., Collier, R.J., Willard, S.T., Arthington, J.D., Brown-Brandl, T.M., 2008. Sweating rates of dairy cows and beef heifers in hot conditions. Trans. ASABE 51 (6), 2167-2178.

Hahn, G.L., Mader, T.L., Gaughan, J.B., Hu, Q., Nienaber, J.A., 1999. Heat waves and their impacts on feedlot cattle. Proc. 15th Int. Soc. Biometeorol. Congr. 353-357.

Hales, J.R.S., Bell, A.W., Fawcett, A.A., King, R.B., 1984. Redistribution of cardiac output and skin AVA activity in sheep during exercise and heat stress. J. Therm. Biol. 9, 113-116.

Houston, D.M., Radostits, O.M., 2000. The clinical examination. In: Radostits, O.M., Mayhew, I.G., Houston, D.M. (Eds.), Veterinary Clinical Examination and Diagnosis. Elsevier, London, pp. 91-124.

Igono, M.O., Bjotvedt, G., Sanford-Crane, H.T., 1992. Environmental profile and critical temperature effects on milk production of Holstein cows in desert climate. Int. J. Biometeorol. 36, 77-87.

Kabuga, J.D., 1992. The influence of thermal conditions on rectal temperature, respiration rate and pulse rate of lactating Holstein-Friesian cows in the humid 
tropics. Int. J. Biometeorol. 36, 146-150.

Kibler, H.H., Johnson, H.D., Shanklin, M.D., Hahn, L., 1965. Environmental physiology and shelter engineering. LXIX. acclimation of Holstein cattle to $29^{\circ} \mathrm{C}$ temperature: changes in heat production and heat dissipation functions. Mo. Agric. Exp. Stn. Res. Bull. 893.

Koong, L.J., Ferrell, C.L., Nienaber, J.A., 1985. Assessment of interrelationships among levels of intake and production, organ size, and fasting heat production in growing animals. J. Nutr. 115, 1383-1390.

Legates, J.E., Farthing, B.R., Casady, R.B., Barrada, M.S., 1991. Body temperature and respiratory rate of lactating dairy cattle under field and chamber conditions. J. Dairy Sci. 74, 2491-2500.

Mader, T.L., Johnson, L.J., Gaughan, J.B., 2010. A comprehensive index for assessing environmental stress in animals. J. Anim. Sci. 88, 2153-2165.

Mader, T.L., Davis, M.S., Brown-Brandl, T., 2006. Environmental factors influencing heat stress in feedlot cattle. J. Anim. Sci. 84, 712-719.

Maust, L.E., McDowell, R.E., Hooven, N.W., 1972. Effect of summer weather on the performance of Holstein cows in three stages of lactation. J. Dairy Sci. 55, 1133-1139.

McDowell, R.E., Hooven, N.W., Camoens, J.K., 1976. Effects of climate on performance of Holsteins in first lactation. J. Dairy Sci. 59, 965-973.

Muller, C.J.C., Botha, J.A., Smith, W.W., 1994. Effect of shade on various parameters of Friesian cows in a Mediterranean climate in South Africa. 1. feed and water intake, milk production and milk composition. South Afr. J. Anim. Sci. 24, 49-55.

Nardone, A., Ronchi, B., Lacetera, N., Ranieri, M.S., Bernabucci, U., 2010. Effects of climate changes on animal production and sustainability of livestock systems. Livest. Sci. 130, 57-69.

Nidumolu, U., Crimp, S., Gobbett, D., Laing, A., Howden, M., Little, S., 2014. Spatiotemporal modelling of heat stress and climate change implications for the Murray dairy region. Aust. Int. J. Biometeorol. 58, 1095-1108.

NRC, 2001. Effect of Environment on Nutrient Requirements of Domestic Animals. National Academy Press, Washington, DC.

Pereira, A.M.F., Baccari Jr, F., Titto, E.A.L., Almeida, J.A.A., 2008. Effect of thermal stress on physiological parameters, feed intake and plasma thyroid hormones concentration in Alentejana, Mertolenga, Frisian and Limousine cattle breeds. Int. J. Biometeorol. 52, 199-208.

Privolo, G., Riva, E., 2009. One-year study of lying and standing behaviour of dairy cows in a freestall barn in Italy. J. Agric. Eng. 2, 27-33.

Pursley, J.R., Mee, M.O., Wiltbank, M.C., 1995. Synchronization of ovulation in dairy cows using PGF2 $\alpha$ and GnRH. Theriogenology 44, 915-923.

Purwanto, B.P., Abo, Y., Sakamoto, R., Furumoto, F., Yamamoto, S., 1990. Diurnal patterns of heat production and heart rate under thermoneutral conditions in Holstein Friesian cows differing in milk production. J. Agric. Sci. (Camb.) 114, 139-142.

Richards, J.I., 1985. Milk production of Friesian cows subjected to high daytime temperatures when allowed food either ad lib or at nighttime only. Trop. Anim. Health Prod. 17, 141-152.

Sanchez, W.K., McGuire, M.A., Beede, D.K., 1994. Macromineral Nutrition by Heat Stress Interactions in Dairy Cattle: review and Original Research. J. Dairy Sci. 77, 2051-2079.

Sanders, A.H., Shearer, J.K., De Vries, A., 2009. Seasonal incidence of lameness and risk factors associated with thin soles, white line disease, ulcers, and sole punctures in dairy cattle. J. Dairy Sci. 92, 3165-3174.

Scharf, B., Carroll, J.A., Riley, D.G., Chase Jr, C.C., Coleman, S.W., Keisler, D.H., Weaber, R.L., Spiers, D.E., 2010. Evaluation of physiological and blood serum differences in heat-tolerant (Romosinuano) and heat-susceptible (Angus) Bos taurus cattle during controlled heat challenge. J. Anim. Sci. 88, 2321-2336.

Shehab-El-Deen, M.A., Fadel, M.S., Van Soom, A., Saleh, S.Y., Maes, D., Leroy, J.L., 2010. Circadian rhythm of metabolic changes associated with summer heat stress in highproducing dairy cattle. Trop. Anim. Health Prod. 42, 1119-1125.

Shwartz, G., Rhoads, M.L., VanBaale, M.J., Rhoads, R.P., Baumgard, L.H., 2009. Effects of a supplemental yeast culture on heat stressed lactating Holstein cows. J. Dairy Sci. 92, 935-942.

Silanikove, N., 2000. Effects of heat stress on the welfare of extensively managed domestic ruminants. Livest. Prod. Sci. 67, 1-18.

Smith, J.F., Brouk, M.J., Harner, J.P., 2003. Heat abatement strategies for optimal dairy cattle performance. In: Proceedings of the Four-State Dairy Nutrition and Management Conference, pp. 99-108.

Soriani, N., Panella, G., Calamari, L., 2013. Rumination time during the summer season and its relationships with metabolic conditions and milk production. J. Dairy Sci. 96, 5082-5094.

Spiers, D.E., Spain, J.N., Sampson, J.D., Rhoads, R.P., 2004. Use of physiological parameters to predict milk yield and feed intake in heat-stressed dairy cows. J. Therm. Biol. 29, 759-764.

Stevens, D.C., 1981. A model of respiratory vapor loss in Holstein dairy cattle. Trans. ASAE 24, 151-153.

St-Pierre, N.R., Cobanov, B., Schnitkey, G., 2003. Economic losses from heat stress by US livestock industries. J. Dairy Sci. 86 (E. Sup.), E52-E77.

Tao, S., Bubolz, J.W., Amaral, B.C., Thompson, I.M., Hayen, M.J., Johnson, S.E., Dahl, G.E., 2011. Effect of heat stress during the dry period on mammary gland development. J. Dairy Sci. 94, 5976-5986.

Thom, E.C., 1959. The discomfort index. Weatherwise 12, 57-59.

Thompson, V.A., Fadel, J.G., Sainz, R.D., 2011. Meta-analysis to predict sweating and respiration rates for Bos indicus, Bos taurus, and their crossbreds. J. Anim. Sci. 89, 3973-3982.

Turner, H.G., Taylor, C.S., 1983. Dynamic factors in models of energy utilization with particular reference to maintenance requirement of cattle. World Rev. Nutr. Diet. 42,
$135-190$.

Van Soest, P.J., Robertson, J.B., Lewis, B.A., 1991. Methods for dietary fiber, neutral detergente fiber, and nonstarch polysaccharides in relation to animal nutrition. J. Dairy Sci. 74, 3583-3597.

Vickers, L.A., Burfeind, O., Von Keyserlingk, M.A.G., Veira, D.M., Weary, D.M., Heuwieser, W., 2010. Technical note: comparison of rectal and vaginal temperatures in lactating dairy cows. J. Dairy Sci. 93, 5246-5251.

Vitali, A., Felici, A., Esposito, S., Bernabucci, U., Bertocchi, L., Maresca, C., Nardone, A., Lacetera, N., 2015. The effect of heat waves on dairy cow mortality. J. Dairy Sci. 98, 4572-4579.

West, J.W., Mullinix, B.G., Bernard, J.K., 2003. Major advances associated with environmental effects on dairy cattle. J. Dairy Sci. 86, 232-242.

Wiles, P.G., Gray, I.K., Kissling, R.C., 1998. Routine analysis of protein by Kjeldahl and Dumas methods: review and interlaboratory study using dairy products. J. AOAC Int. $81,620-632$.

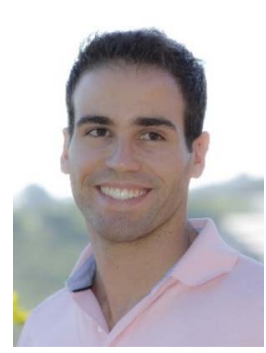

Rodrigo de Andrade Ferrazza B.S. Animal Science, Federal University of Lavras, MG, Brazil (2008); DVM, Federal University of Lavras, MG, Brazil (2012); MSc Anima Science, Federal University of Lavras, MG, Brazil (2012). Academic position: PhD student, Univ Estadual Paulista, Botucatu, SP, Brazil. Areas of expertise: Livestock Management and Animal Reproduction.

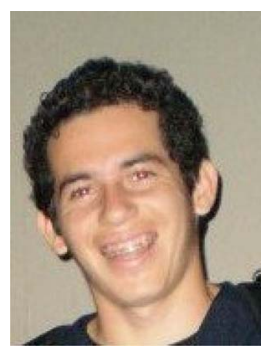

Henry David Mogollón Garcia DVM, University of Pamplona, Colombia (2011); MSc Veterinary Medicine, São Paulo State University, Botucatu, SP, Brazil (2014). Academic position: PhD student, Univ Estadual Paulista, Botucatu, SP, Brazil. Areas of expertise: Animal Reproduction.

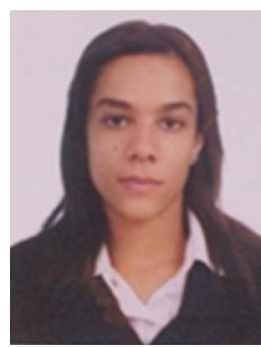

Viviana Helena Vallejo Aristizábal DVM, University of Antioquia, Colombia (2008); MSc Veterinary Medicine, Univ Estadual Paulista, Botucatu, SP, Brazil (2014). Academic position: $\mathrm{PhD}$ student, São Paulo State University, Botucatu, SP, Brazil. Areas of expertise: Animal Reproduction.

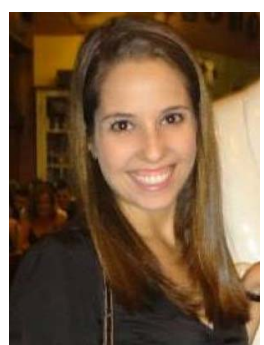

Camilla de Souza Nogueira B.S. Animal Science, Univ Estadual Paulista, Botucatu, SP, Brazil (2014). Academic position: MSc student, São Paulo State University, Botucatu, SP, Brazil. Areas of expertise: Animal Breeding. 


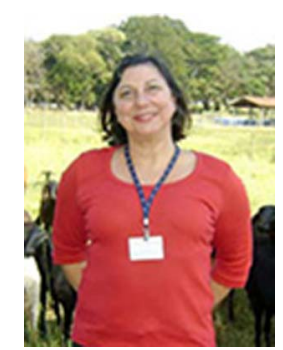

Cecília José Veríssimo DVM, Federal University of Rio de Janeiro, RJ, Brazil (1982); MSc Animal Science, São Paulo State University, SP, Brazil (1991); PhD, Animal Science, São Paulo State University, SP, Brazil (2008). Academic position: Researcher of Animal Science Institute, SP, Brazil. Areas of expertise: Animal Production, Bioclimatology and Diseases Control.

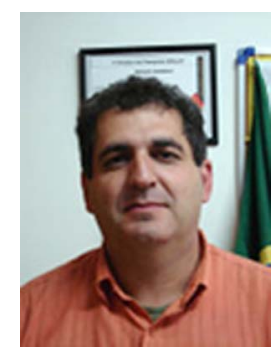

José Roberto Sartori B.S. Animal Science, São Paulo State University, Botucatu, SP, Brazil (1986); MSc Animal Science, Univ Estadual Paulista, Botucatu, SP, Brazil (1996); PhD, Animal Science, São Paulo State University, Jaboticabal, SP, Brazil (2000). Academic position: Assistant Professor of Department of Animal Science, São Paulo State University, Botucatu, SP, Brazil. Areas of expertise: Bioclimatology and Animal Nutrition.

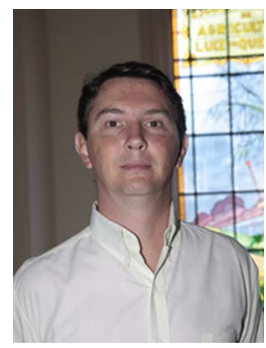

Roberto Sartori DVM, São Paulo State University, Botucatu, SP, Brazil (1992); Residency, Univ Estadual Paulista, Botucatu, SP, Brazil (1995); MSc Veterinary Medicine, São Paulo State University, Botucatu, SP, Brazil (1997); PhD, Dairy Science, University of Wisconsin-Madison, WI, USA (2002). Academic position: Associate Professor of Department of Animal Science, ESALQ, University of São Paulo, Piracicaba, SP, Brazil. Areas of expertise: Reproductive Physiology and Biotechnology in Ruminants.

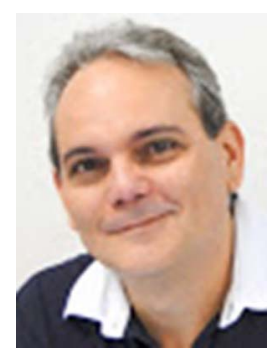

João Carlos Pinheiro Ferreira DVM, Faculty of Agricultural Sciences of Pará, PA, Brazil (1990); Residency, Univ Estadual Paulista, Botucatu, SP, Brazil (1993); MSc Veterinary Medicine, Univ Estadual Paulista, Botucatu, SP, Brazil (1995); PhD, Veterinary Medicine, Univ Estadual Paulista, Botucatu, SP, Brazil (1995); Botucatu, SP, Brazil (2000). Academic position: Assistant Professor of Department of Animal Reproduction and Veterinary Radiology, Univ Estadual Paulista, Botucatu, SP, Brazil. Areas of expertise: Reproduction Physiology, Pathophysiology of Animal Reproduction, Veterinary Obstetrics and Animal Welfare. 